\title{
ASSESSMENT OF THE CONSOLIDATED BREAKOUT RESPONSE OF PARTIALLY EMBEDDED SUBSEA PIPELINES
}

Published in Géotechnique, 64 (5): 391-399. http://dx.doi.org/10.1680/geot.13.P.215

Santiram CHATTERJEE (corresponding author)

Research Associate

Centre for Offshore Foundation Systems - M053

University of Western Australia

35 Stirling Highway, Crawley

Perth, WA 6009

Australia

Email: santiram.chatterjee@uwa.edu.au

\section{Susan GOURVENEC}

Professor

Centre for Offshore Foundation Systems - M053

University of Western Australia

35 Stirling Highway, Crawley

Perth, WA 6009

Australia

Email: susan.gourvenec@uwa.edu.au

\section{David J. WHITE}

Professor

Centre for Offshore Foundation Systems - M053

University of Western Australia

35 Stirling Highway, Crawley

Perth, WA 6009

Australia

Email: david.white@uwa.edu.au

No. of words: 3943 (without abstract and references)

No. of tables: 4

No. of figures: 14 


\title{
Assessment of the Consolidated Breakout Response of Partially Embedded Subsea Pipelines
}

\author{
Santiram Chatterjee, Susan Gourvenec and David J. White
}

\begin{abstract}
The changing soil strength due to consolidation around a subsea pipeline can alter the lateral breakout resistance. Results of elasto-plastic coupled consolidation finite element analyses are presented that quantify the effect of consolidation on the undrained breakout resistance and trajectory of partially embedded seabed pipelines. Breakout resistance is presented in terms of failure envelopes in vertical-horizontal load space, which also allow the trajectory of the pipe during breakout to be determined by normality. Observed responses for consolidated undrained breakout are described by simple algebraic expressions as a function of initial pipe embedment, pipe self-weight (and consequent consolidation pressure) and breakout load path. Consolidation and the associated enhancement of the shear strength of the surrounding soil can have a significant effect on the breakout response. The assumption in current practice of unconsolidated undrained soil behaviour may lead to underestimation of pipeline breakout resistance and inaccurate prediction of the trajectory of the pipe during breakout.
\end{abstract}

Key words: Pipelines, offshore engineering, clays, consolidation, finite-element modelling Words: 3943. Figures: 14. Tables: 4. 
Assessment of the consolidated breakout response of partially embedded subsea pipelines.

\section{Introduction}

Offshore oil and gas developments are moving into deeper and more remote waters with increasing reliance on networks of seabed pipelines between wells and processing platforms. Deepwater offshore pipelines are generally laid directly on the seabed, and are often designed to accommodate lateral buckling due to thermal expansion and contraction of the pipe during operation. The pipe partially embeds into the seabed during the laying process due to its selfweight and a concentration of vertical load associated with the geometry of the pipe catenary where it touches down onto the seabed (Lenci \& Callegari 2005, Randolph \& White 2008a). Once laid, the vertical pipe-soil load is reduced to simply the pipe weight, and the soil around the pipe consolidates. For the typical soft normally-consolidated soils found in deepwater, this consolidation process leads to an increase in the bearing capacity of the soil surrounding the pipeline. In operation, when hot high temperature fluid enters the pipeline, it may be designed to buckle laterally at certain locations where the mobilised pipe-soil resistance exceeds the combined vertical-horizontal (V-H) bearing capacity. To ensure a robust system response, in which the expansion loads are mitigated by regular planned buckles, it is necessary to predict the resistance experienced during lateral breakout, and also the resulting trajectory of the pipe.

Previous studies have explored the undrained breakout behaviour of shallowly embedded pipes. Assessments of undrained breakout resistance have been performed using analytical upper bound limit analysis (Cheuk et al. 2008, Randolph \& White 2008b), small strain finite element analysis (Merifield et al., 2008, Borges \& Oliviera 2011), numerical limit analysis (Martin \& White, 2012), model tests (Oliviera et al. 2010, Lee et al. 2011) and large deformation finite element analysis (Chatterjee et al. 2012a). These studies have established 
Assessment of the consolidated breakout response of partially embedded subsea pipelines.

envelopes of combined V-H bearing capacity, incorporating effects such as soil self-weight, surface heave and the variation of undrained strength with depth.

However, in all of these numerical and analytical studies the undrained shear strength of the soil was invariant, with consolidation not being considered. In reality, consolidation under the pipe self-weight can significantly affect the strength of the surrounding soil, as demonstrated in the present study.

Previous studies of consolidation around seabed pipelines have focussed principally on the timescale of pore pressure dissipation. Gourvenec and White (2010) and Krost et al. (2011) presented elastic solutions of the consolidation response which indicated the extent and longevity of the excess pore pressures around a pipeline but the elastic soil model used in the analyses precluded assessment of the subsequent resistance. Chatterjee et al. (2012b) performed elasto-plastic finite element analysis using the modified Cam clay constitutive model to study consolidation rates around pipelines and these analyses were extended by Chatterjee et al. (2013) to examine the changes in bearing capacity for consolidation under a load equal to the initial undrained bearing capacity.

In this paper, the changing V-H bearing capacity around a shallowly-embedded pipe laid on normally-consolidated soil is investigated. The effects of initial embedment and the load level (relative to the initial bearing capacity) and duration of consolidation are explored. Generalised envelopes are then developed to encompass all of these effects for ease of application.

The present study considers a normally consolidated soil, relevant to many deepwater marine sites. Seabed conditions vary with region and over consolidated deposits or surficial crusts may be encountered (e.g. Kuo \& Bolton, 2013). While the principles of the methodology outlined in this paper can be applied to other soil conditions, the relevance of the specific 
Assessment of the consolidated breakout response of partially embedded subsea pipelines.

results should be considered when applying the method to soil conditions different to those considered in this study.

\section{Finite Element Model and Numerical Parameters}

Small strain two-dimensional plane strain finite element analyses were performed using commercial software Abaqus (Dassault Systèmes, 2011). The pipe was assumed to be wished-in-place at different embedment levels, w/D $=0.1,0.2,0.3,0.4$ and 0.5 . The schematic of a typical finite element model indicating the mesh discretisation and boundary conditions is shown in Figure 1. The boundaries of the model extend to a distance of 8 times the pipe diameter on both sides and below, from the centre of the pipe. The pipe was assumed to be a rigid body and the pipe-soil interface was considered to be perfectly smooth with separation permitted under tensile normal stress. The vertical boundaries were restrained against horizontal movement and the base boundary was restrained against any movement in the vertical or horizontal directions. The soil domain was discretised using 8-noded reduced integration quadrilateral coupled pore fluid plane strain element of type CPE8RP of the Abaqus standard library.

The Modified Cam Clay (MCC) (Roscoe and Burland, 1968) soil constitutive model was used to represent the coupled elasto-plastic stress-pore fluid behaviour. The numerical parameters used for the study are listed in Table 1 and are typical for a Kaolin clay (Stewart, 1992). The soil was considered to be weightless with a surface surcharge, which aids benchmarking against exact plasticity limit analysis results without requiring adjustment for soil buoyancy.

The adoption of weightless surcharged soil yields a uniform value of undrained shear strength throughout the soil domain, since the soil strength is proportional to the consolidation stress level. By modelling weightless soil, the results can be benchmarked against theoretical 
Assessment of the consolidated breakout response of partially embedded subsea pipelines.

solutions for uniform soil. It is important to note that the uniform shear strength profile is not associated with overconsolidation. The initial soil state throughout the domain was normally consolidated such that any stress increase resulting from the pipeline load led to plastic deformation, as is relevant for soft, normally consolidated deepwater marine deposits. A key benefit of this strategy is that the initial coefficient of consolidation, $\mathrm{C}_{\mathrm{v}}$, is uniform throughout the domain, allowing normalisation of the consolidation period without requiring $\mathrm{c}_{\mathrm{v}}$ to be chosen at a specific depth.

A surcharge of $10 \mathrm{kPa}$ was applied at the free surface of the mesh and the initial stresses within the soil mass were isotropic. As the soil initial state was normally consolidated, the initial size of the yield envelope (controlled by the pre-consolidation pressure, $\mathrm{p}_{\mathrm{c}}^{\prime}$ ) was set as the initial mean effective stress $\left(\mathrm{p}_{0}^{\prime}\right)$. The initial void ratio $\left(\mathrm{e}_{0}\right)$ was calculated as

$$
\mathrm{e}_{0}=\mathrm{e}_{\mathrm{cs}}-(\lambda-\kappa) \ln \left(\frac{\mathrm{p}_{\mathrm{c}}^{\prime}}{2}\right)-\kappa \ln \mathrm{p}_{0}^{\prime}
$$

where, $e_{\mathrm{cs}}$ is the void ratio at $1 \mathrm{kPa}$ mean effective stress on the critical state line, $\lambda$ is the slope of the normal consolidation line and $\kappa$ is the slope of an unload-reload line. The ratio between the normally-consolidated undrained shear strength, $s_{u}$ and the vertical effective stress $\sigma_{\mathrm{v}}^{\prime}$ was calculated for plane strain conditions using (Wroth, 1984):

$$
\frac{\mathrm{s}_{\mathrm{u}}}{\sigma_{\mathrm{v}}^{\prime}}=\frac{2}{\sqrt{3}} \frac{\sin \phi_{\mathrm{tc}}}{2 \mathrm{a}}\left(\frac{\mathrm{a}^{2}+1}{2}\right)^{\frac{\lambda-\kappa}{\lambda}}
$$

where,

$$
\mathrm{a}=\frac{3-\sin \phi_{\mathrm{tc}}}{2\left(3-2 \sin \phi_{\mathrm{tc}}\right)}
$$


Assessment of the consolidated breakout response of partially embedded subsea pipelines.

and $\phi_{\mathrm{tc}}$ is the friction angle in triaxial compression. The uniform undrained shear strength, $\mathrm{s}_{\mathrm{u}}$, for the material properties and overburden considered in this study was $2.97 \mathrm{kPa}$, although all results are normalised by this strength so the absolute value is irrelevant.

\section{Methodology}

The pipe was wished-in-place at selected initial normalised embedment depths of $w / D=0.1$, $0.2,0.3,0.4$ and 0.5 . The following sets of analyses were performed:

- Displacement of the pipe in undrained conditions in the downwards vertical and horizontal directions to determine the unconsolidated undrained ultimate loads $\mathrm{V}_{\text {ult,uU }}$ and $\mathrm{H}_{\mathrm{ult}, \mathrm{UU}}$.

- Displacement of the pipe in undrained conditions in other directions at $30^{\circ}$ intervals to determine the full unconsolidated undrained failure envelope in $\mathrm{V}-\mathrm{H}$ space.

- Consolidation under specified vertical loads (corresponding to fractions of $\mathrm{V}_{\mathrm{ult}, \mathrm{UU}}$ ), after initial undrained loading to $\mathrm{V}_{\mathrm{ult}, \mathrm{UU}}$, to determine the rate of pore pressure dissipation, followed by displacement in all direction at $30^{\circ}$ intervals to determine the consolidated undrained failure envelopes in V-H space.

During the consolidation stage, drainage was permitted at the free soil surface on either side of the pipe while the pipe-soil interface was impermeable. The $\mathrm{V}-\mathrm{H}$ failure envelopes indicate both the combination of vertical and horizontal loads that will cause breakout and also the subsequent trajectory of pipe movement, due to normality. For plotting the failure envelopes in $\mathrm{V}-\mathrm{H}$ space, the vertical load (V) and the horizontal load $(\mathrm{H})$ were normalised by $\mathrm{s}_{\mathrm{u}} \mathrm{D}$. All the cases studied are listed in Table 2. The consolidation stage was not performed for w/D = 0.1 due to convergence problems at low stress levels. Only the unconsolidated undrained failure envelope was generated at w/D $=0.1$. 
Assessment of the consolidated breakout response of partially embedded subsea pipelines.

\section{Unconsolidated Undrained Breakout}

The unconsolidated undrained failure envelopes for each embedment level derived from this study are compared with classical plasticity solutions for equivalent conditions (Randolph and White, 2008b) in Figure 2. The plasticity solutions presented by Randolph and White (2008b) modelled the soil as an isotropic rigid-plastic Tresca material characterised by an undrained shear strength su. Undrained shear strength is not an input for the MCC analyses in this study but an equivalent value can be determined using the parameters given in Table 1 and Equation 2. Figure 2 shows that the results from the theoretical analysis and the present finite element analysis are in good agreement.

The ultimate unconsolidated undrained vertical resistance $\left(\mathrm{V}_{\text {ult,UU }}\right)$ and the ultimate unconsolidated undrained horizontal resistance $\left(\mathrm{H}_{\mathrm{ult}, \mathrm{UU}}\right)$ for each embedment level are plotted in Figure 3. The ultimate resistances can be fitted by a simple power equation of the form:

$$
\frac{\mathrm{V}_{\mathrm{ult}, \mathrm{UU}}}{\mathrm{Ds}_{\mathrm{u}}}=5.477\left(\frac{\mathrm{w}}{\mathrm{D}}\right)^{0.276}
$$

and

$$
\frac{\mathrm{H}_{\mathrm{ult}, \mathrm{UU}}}{\mathrm{Ds}_{\mathrm{u}}}=2.816\left(\frac{\mathrm{w}}{\mathrm{D}}\right)^{0.779}
$$

These equations are used subsequently for normalisation of the consolidated undrained capacities.

\section{Excess Pore Pressure Generation and Dissipation}

Undrained loading of the pipe leads to development of excess pore water pressure in the soil around the pipe. An example of the excess pore water pressure normalised by the excess pore 
Assessment of the consolidated breakout response of partially embedded subsea pipelines.

pressure at the pipe invert for the case of $\mathrm{w} / \mathrm{D}=0.5$ is shown in Figure 4 . In the consolidation analyses, the pipe was always initially loaded to $\mathrm{V}_{\text {ult,Uu }}$ before being unloaded to a specified

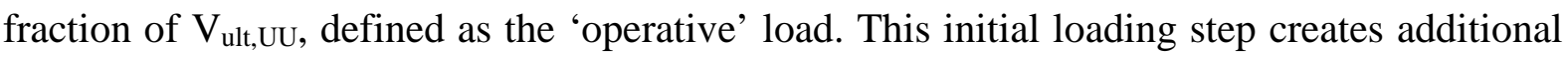
excess pore pressure and represents the lay process in which the pipe is first penetrated, failing the soil, before the vertical pipe-soil load reduces to simply the pipe weight.

A range of operative working loads were assumed for each embedment $\left(\mathrm{V} / \mathrm{V}_{\mathrm{ult}, \mathrm{UU}}=0.25,0.5\right.$, 0.75 and 0.9 ). The pore pressure dissipation time histories in the soil adjacent to the pipe invert for the w/D $=0.5$ case are shown in Figure 5(a). The vertical axis shows the excess pore pressure at a time $\mathrm{t}(\Delta \mathrm{u})$, normalised by the excess pore pressure associated with the initial load step to the ultimate capacity $\left(\Delta \mathrm{u}_{\mathrm{i}, \text { ult }}\right)$. Time is non-dimensionalised as $\mathrm{T}=\frac{\mathrm{C}_{\mathrm{v}} \mathrm{t}}{\mathrm{D}^{2}}$. Here, $\mathrm{C}_{\mathrm{v}}$ is the initial coefficient of consolidation and can be expressed as

$$
\mathrm{c}_{\mathrm{v}}=\frac{\mathrm{k}\left(1+\mathrm{e}_{0}\right) \mathrm{p}_{0}^{\prime}}{\lambda \gamma_{\mathrm{w}}}
$$

where, $\mathrm{k}$ is the permeability of the soil and $\gamma_{\mathrm{w}}$ is the unit weight of water. All the dissipation curves in Figure 5(a) show a sudden drop in the pore pressure at the beginning of consolidation related to the fraction of bearing capacity load maintained on the pipe during consolidation. Normalising by the initial value of excess pore pressure after unloading to the operative load, $\Delta \mathrm{u}_{\mathrm{i}}$ makes all these curves fall in a narrow band (Figure 5(b)). The dissipation history for a particular initial embedment can then be fitted by an exponential equation of the form:

$$
\frac{\Delta \mathrm{u}}{\Delta \mathrm{u}_{\mathrm{i}}}=\mathrm{e}^{-\ln (2) \times\left(\frac{\mathrm{T}}{\mathrm{T}_{50, \text { inv }}}\right)^{\mathrm{n}}}=(0.5)^{\left(\frac{\mathrm{T}}{\mathrm{T}_{50, \text { inv }}}\right)^{\mathrm{n}}}
$$


Assessment of the consolidated breakout response of partially embedded subsea pipelines.

Where, $\mathrm{T}_{50 \text {,inv }}$ is the non-dimensional time required for $50 \%$ dissipation of the excess pore pressure at the invert. The dissipation time histories for $\mathrm{w} / \mathrm{D}=0.2,0.3$ and 0.4 are also fitted to the same equation as shown in Figure 6 . The values of $T_{50, \text { inv }}$ and coefficient ' $n$ ' for all initial embedments are given in Table 3. The responses show that pore pressure dissipation at the pipe invert is practically complete (>95\%) at a dimensionless time of $\mathrm{T} \sim 2$.

\section{Consolidated Undrained Breakout}

Following full primary consolidation, the pipe was displaced in different directions to obtain the consolidated undrained failure envelope for different values of embedment, w/D and

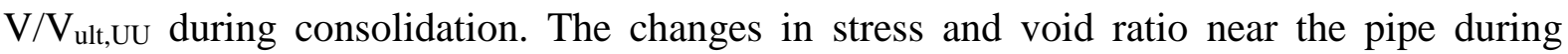
undrained loading, consolidation and subsequent failure can be illustrated by the stress paths in mean effective stress $\left(\mathrm{p}^{\prime}\right)$ - deviatoric stress (q) space and in void ratio (e) - $\ln \left(\mathrm{p}^{\prime}\right)$ space. Stress paths in the soil adjacent to the pipe invert for w/D $=0.5$ and different values of $\mathrm{V} / \mathrm{V}_{\mathrm{ult}, \mathrm{Uu}}$ are shown in Figure 7. In $\mathrm{p}^{\prime}-\mathrm{q}$ space, the stress path starts from point $\mathrm{A}$ on the $\mathrm{q}=0$ axis due to the isotropic initial stress condition. During initial undrained loading to $\mathrm{V}_{\text {ult,uU, the }}$ stress path travels from A to B, which lies on the critical state line. During consolidation, the stress path moves from point B to C1, C2, C3 or C4 depending on the relative magnitude of the consolidation load. The greater the consolidation load, the closer the stress state (at C) lies to the critical state line. Following consolidation, undrained failure (at a load defined as

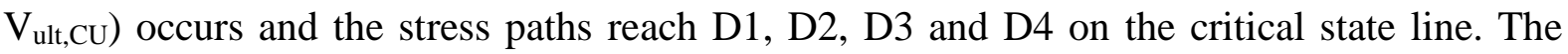
corresponding stress paths are also shown in e-ln( $\left(\mathrm{p}^{\prime}\right)$ space in Figure 7(b).

The consolidated shear strength can be calculated for different values of $\mathrm{V} / \mathrm{V}$ ult,uU as a function of the position of the points D1, D2, D3 and D4. Contours of the ratio of the consolidated undrained shear strength to the initial undrained shear strength, $\mathrm{s}_{\mathrm{u}, \mathrm{cons}} / \mathrm{s}_{\mathrm{u}, \mathrm{init}}$, for different consolidation loads are shown in Figure 8. For, $\mathrm{V} / \mathrm{V}_{\text {ult,UU }}=0.9$, the maximum shear 
Assessment of the consolidated breakout response of partially embedded subsea pipelines.

strength ratio, $\mathrm{s}_{\mathrm{u}, \mathrm{cons}} / \mathrm{s}_{\mathrm{u} \text {,init }} \sim 2$ 2.1. This ratio decreases with decreasing consolidation load, falling to $\sim 1.2$ for $\mathrm{V} / \mathrm{V}_{\text {ult, } \mathrm{UU}}=0.25$. These values can be confirmed from the ratio of $\mathrm{q}$ at $\mathrm{D} 1$, $\mathrm{D} 2, \mathrm{D} 3$ and $\mathrm{D} 4$ to the value at $\mathrm{B}$ in $\mathrm{p}^{\prime}-\mathrm{q}$ space.

The unconsolidated undrained and consolidated undrained failure envelopes for w/D $=0.2$, 0.3, 0.4 and 0.5 are shown in Figure 9. The consolidated undrained resistances are normalised by the initial undrained shear strength, such that the size of the consolidated undrained failure envelopes expands. The expansion is greatest under the highest consolidation load, $\mathrm{V} / \mathrm{V}_{\mathrm{ult}} \mathrm{UU}$ $=0.9$, diminishing with reducing consolidation load. Larger relative increases in capacity are observed at shallower initial embedment for equivalent relative consolidation load. Up to $57 \%$ increase in vertical capacity and 76\% increase in horizontal capacity were observed.

The initial trajectory of the pipe on breakout can be determined from the direction of the normal to the failure envelope, because the normality conditions apply. Figure $9 \mathrm{~d}$ illustrates the effect of consolidation for a case in which the operative vertical load is $\mathrm{V} / \mathrm{s}_{\mathrm{u}} \mathrm{D} \sim 2.25$, and $\mathrm{V} / \mathrm{V}_{\mathrm{ult}, \mathrm{UU}}=0.5$. Under a load path of increasing horizontal load, the unconsolidated case leads to breakout at a load of $\mathrm{H} / \mathrm{s}_{\mathrm{u}} \mathrm{D} \sim 1.5$ (or an equivalent friction of $\mathrm{H} / \mathrm{V} \sim 0.75$ ) and approximately horizontal pipe movement. In contrast, the consolidated undrained breakout resistance is $\mathrm{H} / \mathrm{s}_{\mathrm{u}} \mathrm{D} \sim 2$ (or $\mathrm{H} / \mathrm{V} \sim 0.9$ ) and the pipe will move upwards.

These differences in resistance are relevant to practical conditions. For example, full consolidation around a typical pipeline, with a diameter $\mathrm{D}=0.5 \mathrm{~m}$, initial embedment w/D = 0.2 , on a soft clay for which $c_{v}$ typically lies in the range $100-1 \mathrm{~m}^{2} /$ year, would be expected to occur within 2 - 200 days. Initial loading of the pipeline could occur either before or after this duration. For example, lateral loading due to tension as the pipe is laid around a route curve would generally occur within hours of the pipe first embedding, whereas loading from initial startup or pressure testing would usually occur weeks or months after laying. 
Assessment of the consolidated breakout response of partially embedded subsea pipelines.

\section{Partially-consolidated undrained breakout}

The consolidated undrained failure envelopes presented indicate conditions of full primary consolidation, which was achieved at a non-dimensional time $\mathrm{T}=\mathrm{C}_{\mathrm{v}} \mathrm{t} / \mathrm{D}^{2} \sim 2$. As noted above, cases when only partial consolidation has occurred can be relevant. A method to account for partial consolidation is described in the following section.

\section{Simplified general relationships for consolidated breakout resistance}

The ratio between the consolidated and unconsolidated undrained vertical resistances as a function of consolidation load level is independent of initial embedment (Figure 10) and is fitted by:

$$
\frac{\mathrm{V}_{\mathrm{ult}, \mathrm{CU}}}{\mathrm{V}_{\mathrm{ult}, \mathrm{UU}}}=1+0.6\left(\frac{\mathrm{V}}{\mathrm{V}_{\mathrm{ult}, \mathrm{UU}}}\right)
$$

The increase in the vertical resistance can also be estimated via the increase in shear strength due to consolidation, using an approach set out by Gourvenec et al. (2014) for shallow foundations. The mobilised soil below the pipe is lumped as a single element, for which the operative increment in consolidation stress due to the preload can be estimated as (for initially normally-consolidated conditions):

$$
\Delta \sigma_{c}^{\prime}=f_{\sigma}\left(\frac{V}{D^{\prime}}\right)
$$

where, $\mathrm{V}$ is the applied vertical load during consolidation and $\mathrm{D}^{\prime}$ is the effective diameter of the pipe in contact with the soil (alternatively, the applied stress could be written as the average normal pipe-soil stress, taking account of the wedging effect around the pipe, and the curved perimeter, rather than the chord, $\mathrm{D}^{\prime}$ ). D' can be calculated using: 
Assessment of the consolidated breakout response of partially embedded subsea pipelines.

$$
\mathrm{D}^{\prime}=\mathrm{D} \sin \left(\cos ^{-1}\left(1-\frac{2 \mathrm{w}}{\mathrm{D}}\right)\right)
$$

The applied stress is factored by $f_{\sigma}$ to account for the non-uniform distribution of the stress in the affected zone of soil. The resulting increase in strength of the affected soil is then calculated as:

$$
\Delta \mathrm{s}_{\mathrm{u}}=\mathrm{f}_{\mathrm{su}} \mathrm{R}\left(\Delta \sigma_{\mathrm{c}}^{\prime}\right)
$$

where the shear strength factor $\mathrm{f}_{\text {su }}$ scales the gain in strength of the 'lumped' soil to that mobilised during subsequent failure, and $\mathrm{R}$ is the normally-consolidated strength ratio of the soil, which is 0.258 for the parameters given in Table 1 . Separate scaling factors, $f_{\sigma}$ and $f_{\text {su, }}$ allow the response in over-consolidated conditions to be captured, but in the present normally-consolidated conditions there is effectively a single scaling parameter, $\mathrm{f}_{\sigma} \mathrm{f}_{\text {su. }}$. The bearing capacity is assumed to scale with the change in operative strength, so that

$$
\frac{\mathrm{V}_{\mathrm{ult}, \mathrm{CU}}}{\mathrm{V}_{\mathrm{ult}, \mathrm{UU}}}=\frac{\mathrm{s}_{\mathrm{u}, \text { cons }}}{\mathrm{s}_{\mathrm{u}, \text { init }}}=1+\left(\frac{\Delta \mathrm{s}_{\mathrm{u}}}{\mathrm{s}_{\mathrm{u}, \text { init }}}\right)
$$

Gourvenec et al. (2014) show that values of $\mathrm{f}_{\sigma}=0.8$ and $\mathrm{f}_{\mathrm{su}}=0.45$ provide good predictions for the consolidated bearing capacity of surface strip and circular foundations. The same parameters underpredict the results in the present paper by $20 \%$, as shown in Figure 10. Instead, excellent agreement is achieved using a higher value of $\mathrm{f}_{\mathrm{su}}=0.56$, or $\mathrm{f}_{\sigma} \mathrm{f}_{\mathrm{su}}=0.45$.

This contrast in the $\mathrm{f}_{\text {su }}$ parameter between surface foundations and pipelines is perhaps due to the additional normal stress applied to the surrounding soil by the 'wedging' effect (Krost et al., 2011) caused by the curved pipeline surface. This additional loading creates a greater rise in soil strength than the purely vertical load applied by a surface foundation. 
Assessment of the consolidated breakout response of partially embedded subsea pipelines.

This result provides a useful illustration of the influence of the pipe weight on the strength of the surrounding soil. Without the benefit of these analyses, it might be assumed that the surrounding soil reaches a shear strength equal to the normally-consolidated strength under a consolidation stress equal to the pipe bearing stress (i.e. $s_{u}=R V / D^{\prime}$ ), and that this strength controls the consolidated vertical bearing capacity. This assumption implies $\mathrm{f}_{\sigma} \mathrm{f}_{\mathrm{su}}=1$, in the terminology of Gourvenec et al. (2014), and is indicated by the dotted line in Figure 10. In fact, the actual gain in bearing capacity seen in the FE analyses is approximately half of this value.

The consolidated undrained horizontal ultimate resistance $\mathrm{H}_{\mathrm{ult}, \mathrm{CU}}$ relative to $\mathrm{H}_{\mathrm{ult}, \mathrm{UU}}$ varies with embedment (Figure 11) and is fitted by an exponential expression of the form:

$$
\frac{\mathrm{H}_{\mathrm{ult}, \mathrm{CU}}}{\mathrm{H}_{\mathrm{ult}, \mathrm{UU}}}=\mathrm{e}^{\left(\frac{\mathrm{V} / \mathrm{V}_{\mathrm{ult}, \mathrm{UU}}}{1.24+1.6(\mathrm{w} / \mathrm{D})}\right)}
$$

$\mathrm{V}_{\text {ult,Uu }}$ and $\mathrm{H}_{\text {ult,Uu }}$ can be calculated from Equations 4 and 5, and $\mathrm{V}_{\text {ult,Cu }}$ and $\mathrm{H}_{\text {ult,Cu can then }}$ be calculated using Equations 8 and 13 respectively. All of the ultimate vertical and horizontal resistances can be used to normalise the respective failure envelopes (Figure 9) leading to the unique narrow band shown in Figure 12. This can be fitted to a simple sine curve of the form:

$$
\frac{\mathrm{H}}{\mathrm{H}_{\mathrm{ult}}}=\left(\sin \left(\pi \times\left(\frac{\mathrm{V}}{\mathrm{V}_{\mathrm{ult}}}\right)\right)\right)^{0.5}
$$

Equation (14) can then be used to calculate failure envelopes for any value of initial embedment and consolidation load using the respective $\mathrm{V}_{\text {ult }}$ and $\mathrm{H}_{\text {ult }}$ values as explained earlier. The values of consolidated undrained ultimate vertical and horizontal resistances as described in Equations 8 and 13 are valid if full consolidation has occurred. 
Assessment of the consolidated breakout response of partially embedded subsea pipelines.

\section{Extension to partially-consolidated conditions}

For the case of partial consolidation, the gains in capacity given by Equations 8 and 13 must be scaled to allow for the partial dissipation of excess pore pressure and therefore the lower increase in undrained strength. Additional analyses were performed to assess the breakout resistance after partial pore pressure dissipation. These analyses indicated that the increase in ultimate resistance - which arises from the dissipation of pore pressure within the soil zone loaded during breakout - follows an exponential trend with time. However, this trend lags behind the pore pressure dissipation at the pipe invert, so alternative time factors, $\mathrm{T}_{50, \mathrm{H}}$ and $\mathrm{T}_{50, \mathrm{~V}}$ are defined. The values of $\mathrm{n}$ are kept same as those in Table 3 . The ultimate vertical resistance after partial consolidation $\mathrm{V}_{\text {ult,PCU }}$ and the ultimate horizontal resistance after partial consolidation $\mathrm{H}_{\mathrm{ult}, \mathrm{PCU}}$ can be found out using

$$
\begin{aligned}
& \frac{\mathrm{V}_{\mathrm{ult}, \mathrm{PCU}}-\mathrm{V}_{\mathrm{ult}, \mathrm{UU}}}{\mathrm{V}_{\mathrm{ult}, \mathrm{CU}}-\mathrm{V}_{\mathrm{ult}, \mathrm{UU}}}=1-\mathrm{e}^{-\ln (2) \times\left(\frac{\mathrm{T}}{\mathrm{T}_{50, \mathrm{~V}}}\right)^{\mathrm{n}}} \\
& \frac{\mathrm{H}_{\mathrm{ult}, \mathrm{PCU}}}{\mathrm{H}_{\mathrm{ult}, \mathrm{UU}}}=\left(\frac{\mathrm{H}_{\mathrm{ult}, \mathrm{CU}}}{\mathrm{H}_{\mathrm{ult}, \mathrm{UU}}}\right)^{\left(1-\mathrm{e}^{\left.-\ln (2) \times\left(\frac{\mathrm{T}}{\mathrm{T}_{50, \mathrm{H}}}\right)^{\mathrm{n}}\right)}\right.}
\end{aligned}
$$

$\mathrm{T}_{50, \mathrm{H}}$ varies with embedment and is twice $\mathrm{T}_{50, \text { inv }}$, whereas $\mathrm{T}_{50, \mathrm{~V}}$ is constant with embedment. Figure 13 and Figure 14 show the variation of $\mathrm{V}_{\text {ult,PCU}} / \mathrm{V}_{\text {ult,uU }}$ and $\mathrm{H}_{\mathrm{ult}, \mathrm{PCu}} / \mathrm{H}_{\mathrm{ult}, \mathrm{UU}}($ for w/D $=$ 0.2 ) with consolidation load $\mathrm{V} / \mathrm{V}_{\mathrm{ult}, \mathrm{UU}}$ for different values of $\mathrm{T}$. The values of $\mathrm{T}_{50, \mathrm{~V}}, \mathrm{~T}_{50, \mathrm{H}}$ and $\mathrm{n}$ are given in Table 4.

It should be noted that these results are from small strain finite element analyses and hence do not account for the formation of soil heave during penetration. As seen in previous studies in which the berm was represented, either by small strain or by large deformation analyses 
Assessment of the consolidated breakout response of partially embedded subsea pipelines.

(Gourvenec \& White 2010, Chatterjee et al. 2012b), the presence of a soil berm can lead to slightly delayed dissipation and increased resistance.

\section{Effect of soil buoyancy}

All the results presented in this study are obtained assuming weightless soil. If required, the effect of soil weight can be incorporated by an adjustment to the measured ultimate vertical and horizontal resistances for weightless soil according to the following equations.

$$
\begin{aligned}
& \left(\frac{\mathrm{V}}{\mathrm{Ds}_{\mathrm{u}}}\right)_{\text {weighty }}=\left(\frac{\mathrm{V}}{\mathrm{Ds}_{\mathrm{u}}}\right)_{\text {weightless }}+\mathrm{f}_{\mathrm{bv}} \frac{\gamma^{\prime} \mathrm{A}_{\mathrm{s}}}{\mathrm{Ds}_{\mathrm{u}}} \\
& \left(\frac{\mathrm{H}}{\mathrm{Ds}_{\mathrm{u}}}\right)_{\text {weighty }}=\left(\frac{\mathrm{H}}{\mathrm{Ds}_{\mathrm{u}}}\right)_{\text {weightless }}+\mathrm{f}_{\mathrm{bh}} \frac{\gamma^{\prime} \mathrm{A}_{\mathrm{s}}}{\mathrm{Ds}_{\mathrm{u}}}
\end{aligned}
$$

Here, $\gamma^{\prime}$ is the effective unit weight of the soil and $A_{s}$ is the submerged area of the pipe crosssection below mudline. $f_{b v}$ and $f_{b h}$ are the buoyancy factors for vertical and horizontal resistances respectively (Randolph \& White 2008a, Merifield et al. 2009). According to Archimedes' principle, $f_{b v}$ is equal to one for pure downward vertical movement (if soil heave is not present). For pure horizontal motion with a gap opening at the rear of the pipe, $f_{b v}=0.5$ and the equivalent work done is same as pushing against a vertical wall of depth w. For a small horizontal movement $\delta \mathrm{u}$, the work done lifting the soil $=\left(\gamma^{\prime} w \delta \mathrm{u}\right) \times(\mathrm{w} / 2)$ whilst the work input is defined through the buoyancy term above as $=f_{b h}\left(\gamma^{\prime} A_{s} \delta u\right)$. This implies that for pure horizontal movement and breakaway occurring,

$$
\mathrm{f}_{\mathrm{bh}}=\frac{0.5 \mathrm{w}^{2}}{\mathrm{~A}_{\mathrm{s}}}
$$

The submerged pipe area can be calculated using, 
Assessment of the consolidated breakout response of partially embedded subsea pipelines.

$$
A_{s}=\frac{D^{2}}{4}(\beta-\sin \beta \cos \beta)
$$

where

$$
\beta=\cos ^{-1}\left(1-\frac{2 \mathrm{w}}{\mathrm{D}}\right)
$$

\section{Concluding Remarks}

Results from coupled elasto-plastic pore-fluid stress finite element analysis have been presented to show the effects of consolidation on the breakout response of shallowly embedded deepwater pipelines. The strength increase resulting from consolidation has been shown to lead to significant increases in the subsequent undrained breakout resistance and associated changes in pipe trajectory during breakout. As a result, over the time period between pipe laying and operation there may be significant changes in breakout behaviour, which are not currently considered in design practice.

A simple calculation methodology is presented that enables prediction of the consolidated undrained breakout resistance and the trajectory during breakout of seabed pipelines as a function of initial embedment, pipe self-weight during consolidation and the period of consolidation. All the required parameters are expressed through algebraic expressions so the method is conducive to incorporation into a simple spreadsheet program. The methodology presented can be applied to predict the breakout failure envelopes of partially embedded pipes for any initial embedment and consolidation load, at any time after the start of consolidation.

The contribution of the paper is to provide a basis to assess the consolidated undrained breakout behaviour of partially embedded seabed pipelines which has not been systematically addressed to date. The accurate assessment of initial breakout behaviour is very important for 
Assessment of the consolidated breakout response of partially embedded subsea pipelines.

designing deepwater pipelines against lateral buckling. Current design practice assumes only unconsolidated undrained behaviour, which may be inappropriate and inaccurate given that there is a time lag between laying and actual operation. Results from unconsolidated undrained analyses of breakout behaviour are widely reported in the literature. However, the inevitable influence of consolidation has not been considered in previous studies - the present paper overcomes that limitation. The effects of consolidation have been shown to be potentially significant and quantified using simple curve fits. These are useful and can be used easily in engineering practice.

The methodology described in this paper is valid for normally consolidated sediments, which is the typical condition found in deep water offshore. Careful consideration of the applicability of this method is required in other conditions: over-consolidated soil will generally show a lower gain in strength due to the pipe weight and the response of structured seabed surface 'crusts' may also be different.

\section{Acknowledgements}

The work described in this paper forms the part of activities at the Centre for Offshore Foundation Systems (COFS) at the University of Western Australia, currently supported as a node of the Australian Research Council Centre of Excellence for Geotechnical Science and Engineering. The third author is supported by Shell Australia, via the Shell EMI Chair of Offshore Engineering.

\section{Notation}
$\mathrm{A}_{\mathrm{s}} \quad$ Submerged area of the pipe cross section
$\mathrm{C}_{\mathrm{v}} \quad$ Coefficient of consolidation
D Pipe diameter
D' $\quad$ Effective pipe diameter
$\Delta \mathrm{s}_{\mathrm{u}} \quad$ Increase in shear strength due to consolidation 
Assessment of the consolidated breakout response of partially embedded subsea pipelines.

$\Delta \mathrm{u} \quad$ Excess pore water pressure

$\Delta \mathrm{u}_{\mathrm{i}, \mathrm{ult}} \quad$ Excess pore pressure associated with the ultimate capacity

$\Delta \sigma_{\mathrm{c}}^{\prime} \quad$ Operative increment in consolidation stress

$\mathrm{e}_{0} \quad$ Initial void ratio

e $\quad$ Void ratio at $1 \mathrm{kPa}$ mean effective stress on the critical state line

$\mathrm{f}_{\mathrm{bv}} \quad$ Buoyancy factor for vertical resistance

$f_{b h} \quad$ Buoyancy factor for horizontal resistance

$\mathrm{f}_{\sigma}$

Stress factor in Equation 9

$\mathrm{f}_{\mathrm{su}}$

Strength factor in Equation 11

$\gamma^{\prime}$

Effective unit weight of the soil

$\gamma_{\mathrm{w}} \quad$ Unit weight of water

$\mathrm{H}$

Horizontal resistance

$\mathrm{H}_{\mathrm{ult}, \mathrm{UU}} \quad$ Ultimate unconsolidated undrained horizontal load

$\mathrm{H}_{\mathrm{ult}, \mathrm{CU}} \quad$ Ultimate consolidated undrained horizontal load after full consolidation

$\mathrm{H}_{\mathrm{ult}, \mathrm{PCU}} \quad$ Ultimate consolidated undrained horizontal load after partial consolidation

k Permeability of the soil

$\kappa$

Slope of unload-reload line

$\lambda$

Slope of normal consolidation line

$\mathrm{p}_{0}^{\prime} \quad$ Mean effective stress

$\mathrm{p}_{\mathrm{c}}^{\prime} \quad$ Pre-consolidation pressure

q Deviatoric stress

R Normally-consolidated strength ratio

$\mathrm{S}_{\mathrm{u}} \quad$ Undrained shear strength

Su,init Initial undrained shear strength 
Assessment of the consolidated breakout response of partially embedded subsea pipelines.

$\begin{array}{ll} & \text { Consolidated undrained shear strength } \\ \sigma_{\mathrm{v}}^{\prime} & \text { Vertical effective stress } \\ \sigma_{\mathrm{v} 0}^{\prime} & \text { Initial vertical effective stress } \\ \mathrm{t} & \text { Time of consolidation } \\ \mathrm{T} & \text { Non-dimensional time factor of consolidation } \\ \mathrm{T}_{50, \text { inv }} & \text { Non-dimensional time factor for } 50 \% \text { dissipation at the invert } \\ \mathrm{T}_{50, \mathrm{H}} & \text { Non-dimensional time factor for } 50 \% \text { dissipation for vertical resistance } \\ \mathrm{T}_{50, \mathrm{~V}} & \text { Vertical resistance } \\ \mathrm{V} & \text { Ultimate unconsolidated undrained vertical load } \\ \mathrm{V}_{\mathrm{ult}, \mathrm{UU}} & \text { Ultimate consolidated undrained vertical load after full consolidation } \\ \mathrm{V}_{\mathrm{ult}, \mathrm{CU}} & \text { Ultimate consolidated undrained vertical load after partial consolidation } \\ \mathrm{V}_{\mathrm{ult}, \mathrm{PCU}} & \\ \mathrm{w} & \end{array}$

\section{References}

Borges, R.G. \& Oliviera, J.R.M.S. (2011). Multidirectional analysis of pipeline-soil interaction in clay. Proc. 2nd Int. Symp. on Frontiers in Offshore Geotechnics, Perth, 773-778.

Chatterjee, S., White, D.J. \& Randolph, M.F. (2012a). Numerical simulations of pipe-soil interaction during large lateral movements on clay. Géotechnique 62, No. 8, 693705.

Chatterjee, S., Yan, Y., Randolph, M.F. \& White, D.J. (2012b). Elastoplastic consolidation beneath shallowly embedded offshore pipelines. Géotechnique Letters 2, 73-79. 
Assessment of the consolidated breakout response of partially embedded subsea pipelines.

Chatterjee, S., White, D.J. \& Randolph, M.F. (2013). Coupled consolidation analysis of pipesoil interactions. Canadian Geotechnical Journal 50, No. 6, 609-619.

Cheuk, C.Y., White, D.J. \& Dingle, H.R.C. (2008). Upper bound plasticity analysis of a partially-embedded pipe under combined vertical and horizontal loading. Soils and Foundations 48, No. 1, 133-140.

Dassault Systèmes. (2011). Abaqus Analysis Users' Manual. Simulia Corp, Providence, RI, USA.

Gourvenec, S.M., Vulpe, C. \& Murthy, T.G. (2014). A method for predicting the consolidated undrained bearing capacity of shallow foundations. Géotechnique $\mathbf{6 4}$, No. 3, 215-225. http://dx.doi.org/10.1680/geot.13.P.101.

Gourvenec, S. \& White, D.J. (2010). Elastic solutions for consolidation around seabed pipelines. Proc. Offshore Technology Conference, Houston, OTC 20554.

Krost, K., Gourvenec, S. \& White, D.J. (2011). Consolidation around partially embedded submarine pipelines. Géotechnique 61, No. 2, 167-173.

Kuo, M.Y-H. \& Bolton, M.D. (2013), The nature and origin of deep ocean clay crust from the Gulf of Guinea. Géotechnique 63, No. 6, 500-509, http://dx.doi.org/10.1680/geot.10.P.012.

Lenci, S. \& Callegari, M. (2005). Simple analytical models for the J-lay problem. Acta Mechanica 178, 23-39.

Lee, Y.S., Smith, C.C. \& Cheuk, C.Y. (2011). Lateral breakout resistance of shallowly embedded offshore pipelines. Procedia Engineering 14, 1690-1695.

Martin, C.M. \& White, D.J. (2012). Limit analysis of the undrained bearing capacity of offshore pipelines. Géotechnique 62, No. 9, 847-863. 
Assessment of the consolidated breakout response of partially embedded subsea pipelines.

Merifield, R., White, D.J. \& Randolph, M.F. (2008). The ultimate undrained resistance of partially embedded pipelines. Géotechnique 58, No. 6, 461-470.

Oliviera, J.M.R.S., Almeida, M.S.S., Almeida, M.C.F. \& Borges, R.G. (2010). Physical modelling of lateral clay-pipe interaction. J. Geotech. Geoenviron. Engng 136, No. 7, 950-956.

Randolph, M.F. \& White, D.J. (2008a). Pipeline embedment in deep water: process and quantitative assessment. Proc. Offshore Technology Conference, Houston, OTC 19128-PP.

Randolph, M.F. \& White, D.J. (2008b). Upper-bound yield envelopes for pipelines at shallow embedment in clay. Géotechnique 58, No. 4, 297-301.

Roscoe, K.H. \& Burland, J.B. (1968). On the generalised stress-strain behaviour of 'wet clay'. Engineering Plasticity, Cambridge University Press, 535-609.

Stewart, D.P. (1992). Lateral loading of piled bridge abutments due to embankment construction. PhD thesis, The University of Western Australia.

Wroth, C.P. (1984). The interpretation of in situ soil tests. Géotechnique 34, No. 4, 449-489. 
Assessment of the consolidated breakout response of partially embedded subsea pipelines.

\section{List of Tables}

Table 1 Input parameters for numerical analyses

\begin{tabular}{|c|c|}
\hline Parameter & Value \\
\hline Slope of critical state line (CSL), $\mathrm{M}$ & 0.92 \\
\hline Void ratio (at $\mathrm{p}^{\prime}=1 \mathrm{kPa}$ on CSL), $\mathrm{e}_{\mathrm{cs}}$ & 2.14 \\
\hline Slope of normal consolidation line, $\lambda$ & 0.205 \\
\hline Slope of swelling line, $\kappa$ & 0.044 \\
\hline Poisson's ratio, $\mu$ & 0.3 \\
\hline Unit weight of water, $\gamma_{\mathrm{w}}$ & $10 \mathrm{kN} / \mathrm{m}^{3}$ \\
\hline Permeability of soil, $\mathrm{k}$ & $1 \times 10^{-9} \mathrm{~m} / \mathrm{s}$ \\
\hline
\end{tabular}

Table 2 Cases considered in numerical analysis

\begin{tabular}{|c|c|c|c|}
\hline Case & w/D & V/Vult,UU & $\begin{array}{c}\text { Direction of pipe } \\
\text { movement to vertical }\end{array}$ \\
\hline $\begin{array}{c}\text { Unconsolidated } \\
\text { undrained }\end{array}$ & $0.1,0.2,0.3,0.4,0.5$ & - & $\begin{array}{c}0^{\circ}, 30^{\circ}, 60^{\circ}, 90^{\circ}, 120^{\circ}, \\
150^{\circ} \text { and } 180^{\circ}\end{array}$ \\
\hline $\begin{array}{c}\text { Consolidated } \\
\text { undrained }\end{array}$ & $0.2,0.3,0.4,0.5$ & $\begin{array}{c}0.9,0.75,0.5 \text { and } \\
0.25\end{array}$ & $\begin{array}{c}0^{\circ}, 30^{\circ}, 60^{\circ}, 90^{\circ}, 120^{\circ}, \\
150^{\circ} \text { and } 180^{\circ}\end{array}$ \\
\hline
\end{tabular}

Table 3 Parameters for pore pressure decay at invert (Equation 7)

\begin{tabular}{|c|c|c|}
\hline Initial embedment, w/D & $\mathrm{T}_{50, \text { inv }}$ & $\mathrm{n}$ \\
\hline 0.2 & 0.025 & 0.54 \\
\hline 0.3 & 0.035 & 0.55 \\
\hline 0.4 & 0.050 & 0.58 \\
\hline 0.5 & 0.065 & 0.62 \\
\hline
\end{tabular}

Table 4 Parameters for rate of gain in capacity (Equation 15)

\begin{tabular}{|c|c|c|c|}
\hline Initial embedment, w/D & $\mathrm{T}_{50, \mathrm{~V}}$ & $\mathrm{~T}_{50, \mathrm{H}}$ & $\mathrm{n}$ \\
\hline 0.2 & 0.28 & 0.05 & 0.54 \\
\hline 0.3 & 0.28 & 0.07 & 0.55 \\
\hline 0.4 & 0.28 & 0.10 & 0.58 \\
\hline 0.5 & 0.28 & 0.13 & 0.62 \\
\hline
\end{tabular}


Assessment of the consolidated breakout response of partially embedded subsea pipelines.

\section{List of Figures:}

Figure 1 Finite element model $(w / D=0.5)$

Figure 2 Comparison of calculated unconsolidated undrained pipe breakout resistance and theoretical solution

Figure 3 Variation of unconsolidated undrained vertical and horizontal capacity with initial embedment

Figure 4 Distribution of excess pore water pressure after undrained penetration

Figure 5 Invert pore pressure dissipation time histories during consolidation $(\mathrm{w} / \mathrm{D}=0.5)$

Figure 6 Fitted invert pore pressure dissipation time histories for range of embedment

Figure 7 Stress paths at pipe invert during loading and consolidation $(\mathrm{w} / \mathrm{D}=0.5)$

Figure 8 Distribution of shear strength enhancement due to consolidation

Figure 9 Failure envelopes for unconsolidated and consolidated breakout

Figure 10 Gain in undrained vertical capacity due to consolidation

Figure 11 Gain in undrained horizontal capacity due to consolidation

Figure 12 Normalised failure envelopes for consolidated undrained breakout

Figure 13 Effect of partial consolidation on undrained vertical capacity

Figure 14 Effect of partial consolidation on undrained horizontal capacity $(\mathrm{w} / \mathrm{D}=0.2)$ 
Assessment of the consolidated breakout response of partially embedded subsea pipelines.

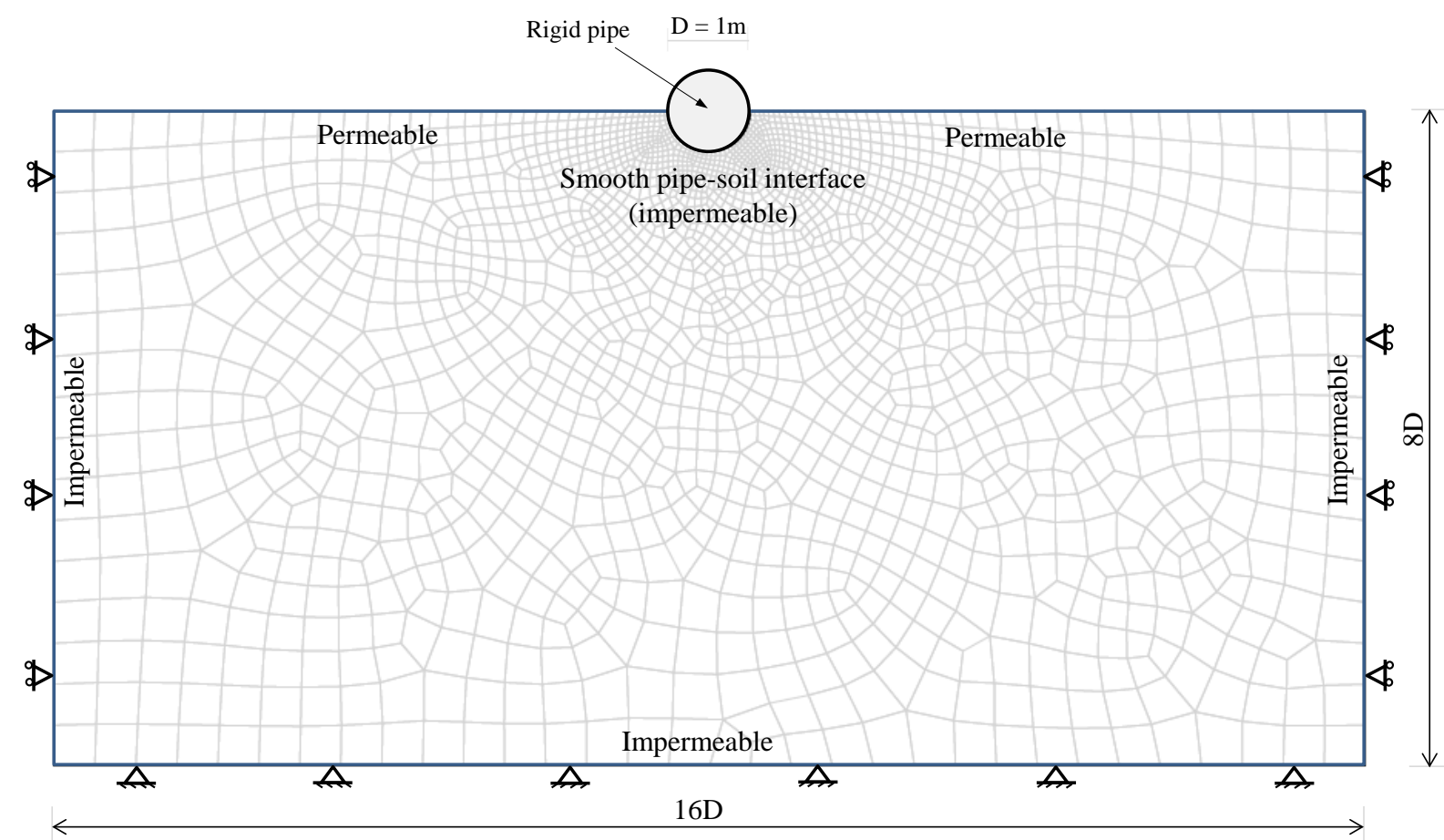

Figure 1 Finite element model $(w / D=0.5)$

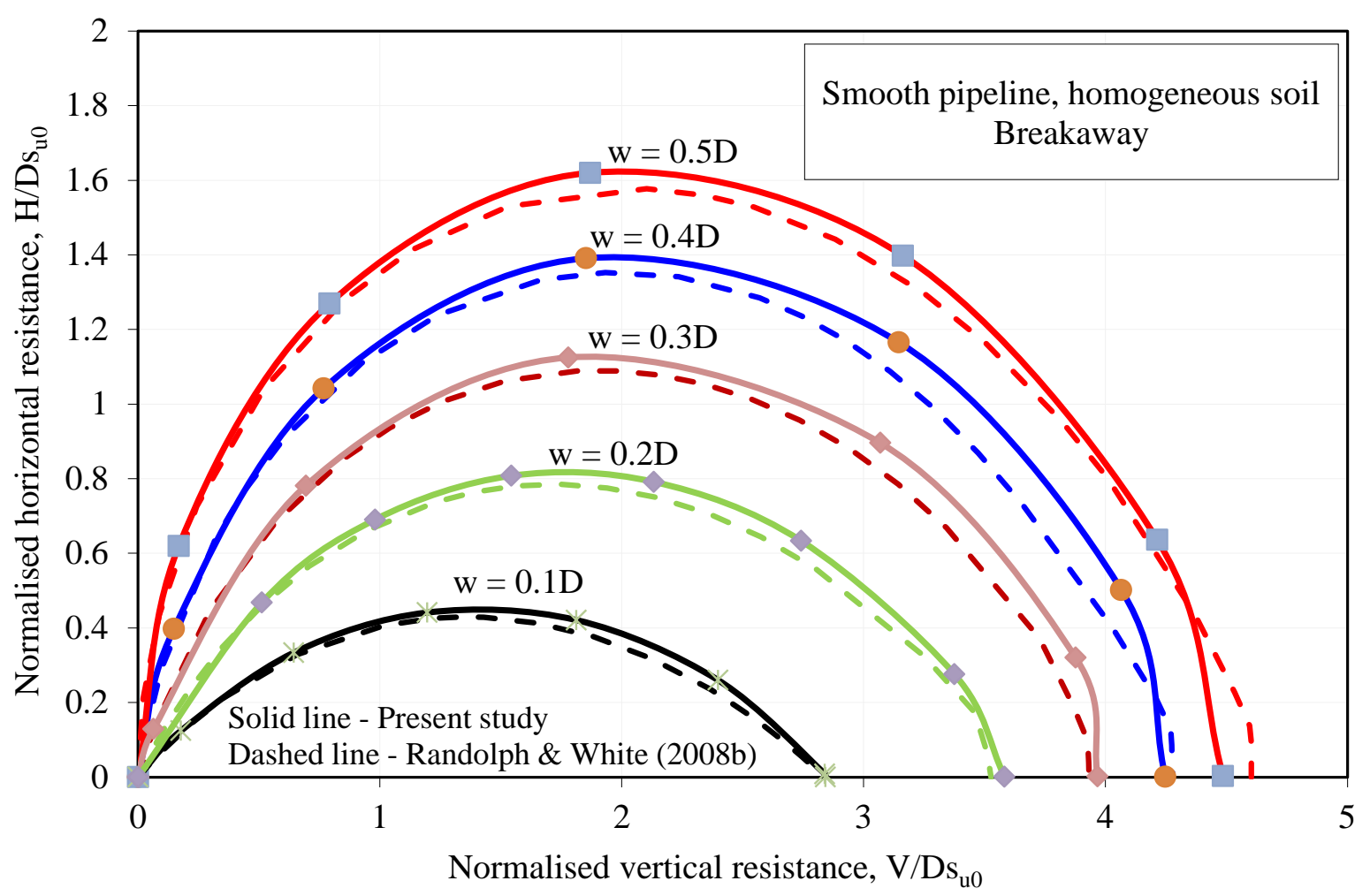

Figure 2 Comparison of calculated unconsolidated undrained pipe breakout resistance and theoretical solution 


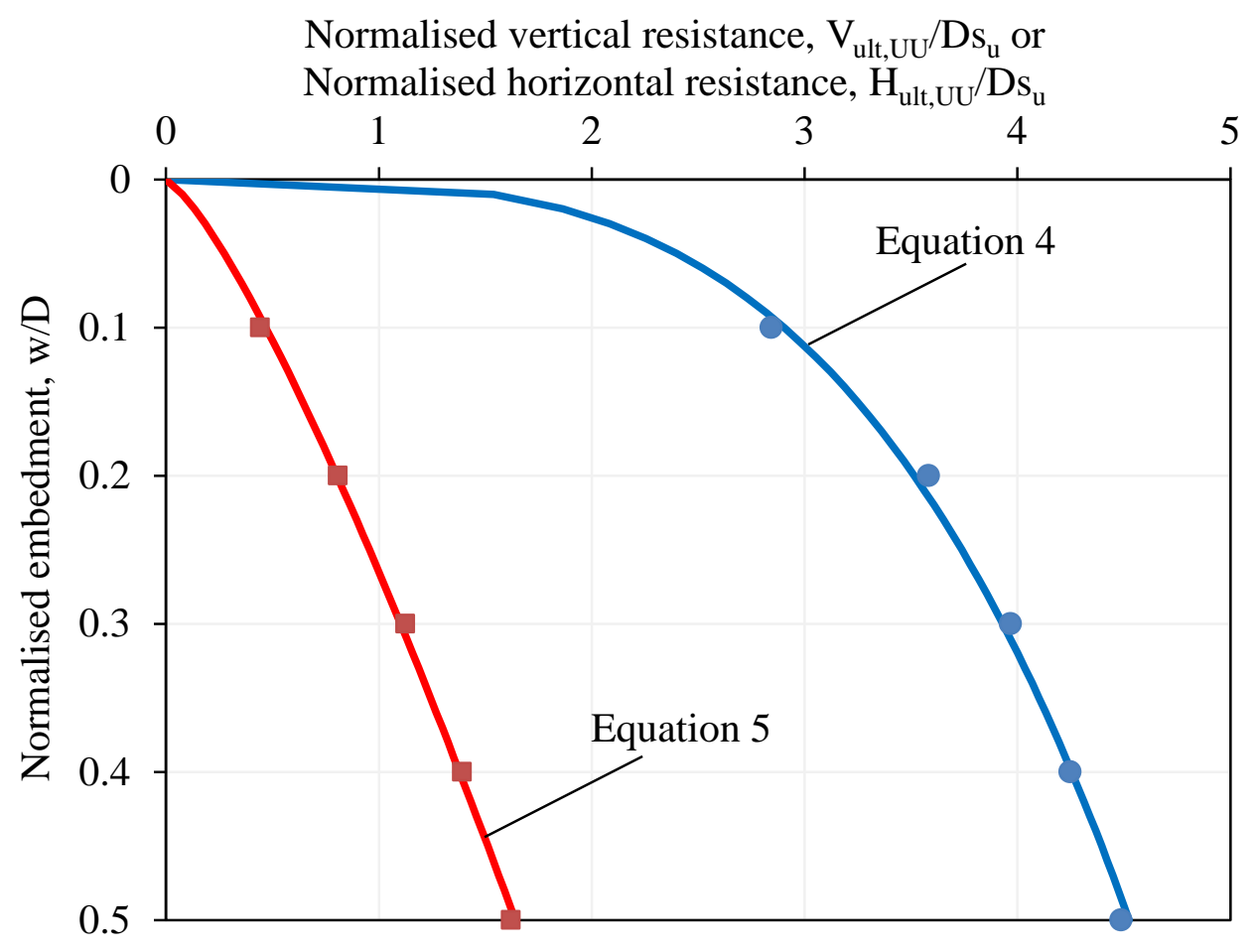

Figure 3 Variation of unconsolidated undrained vertical and horizontal capacity with initial embedment

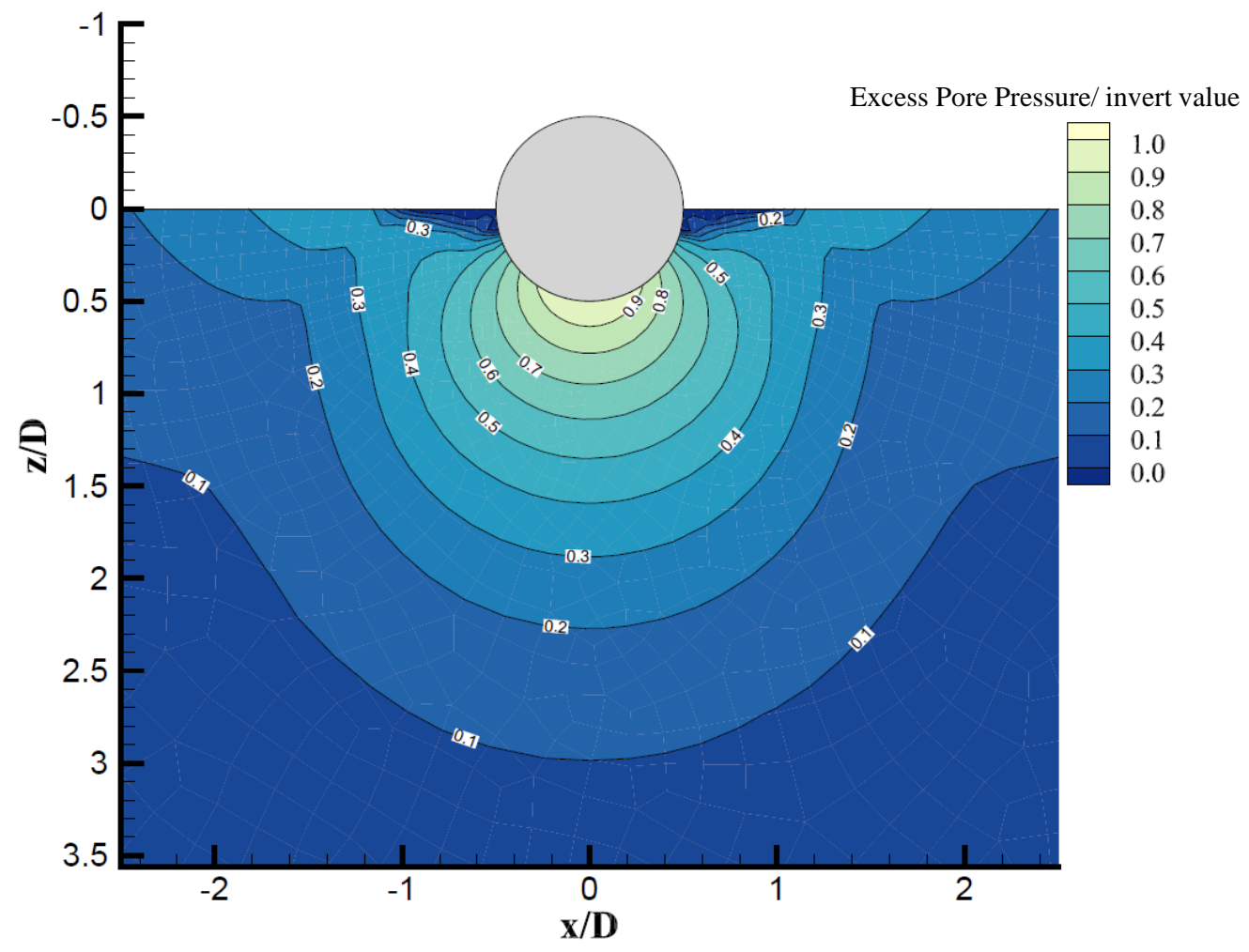

Figure 4 Distribution of excess pore water pressure after undrained penetration 


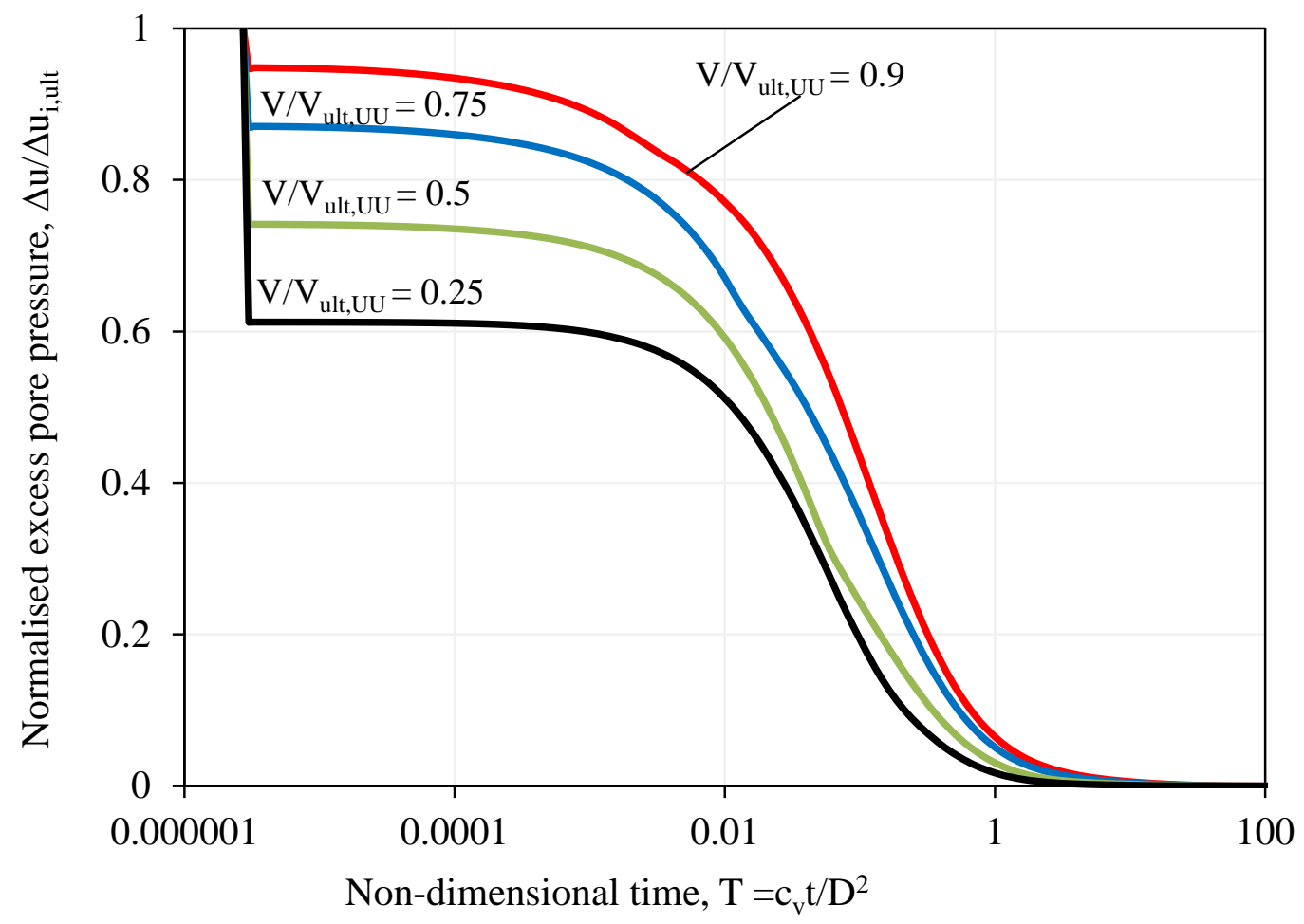

(a) Normalising by initial excess pore pressure at vertical capacity $\left(\Delta \mathrm{u}_{\mathrm{i}, \mathrm{ult}}\right)$

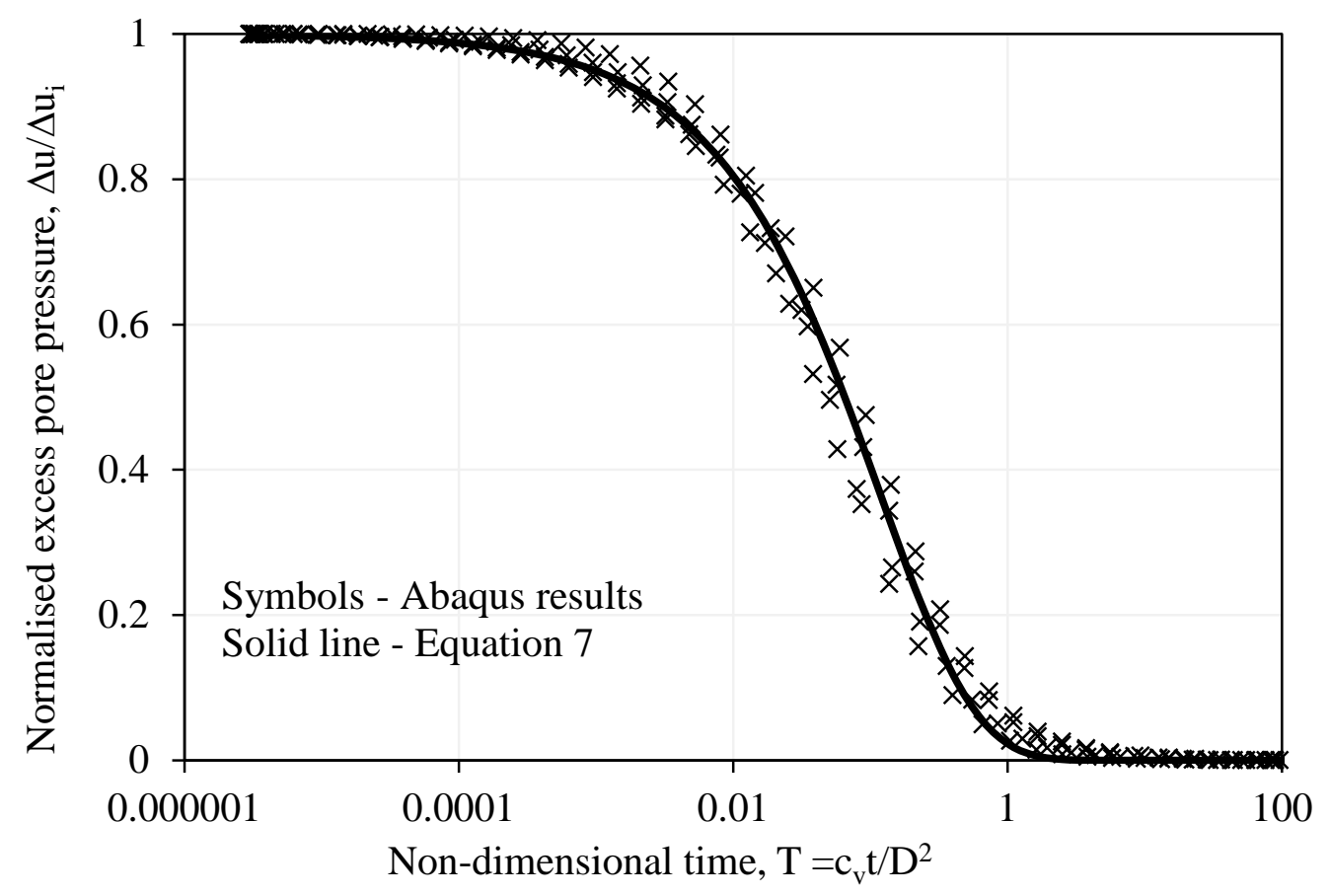

(b) Normalised by initial excess pore pressure under operative consolidation load $\left(\Delta \mathrm{u}_{\mathrm{i}}\right)$

Figure 5 Invert pore pressure dissipation time histories during consolidation, w/D $=0.5$ 
Assessment of the consolidated breakout response of partially embedded subsea pipelines.

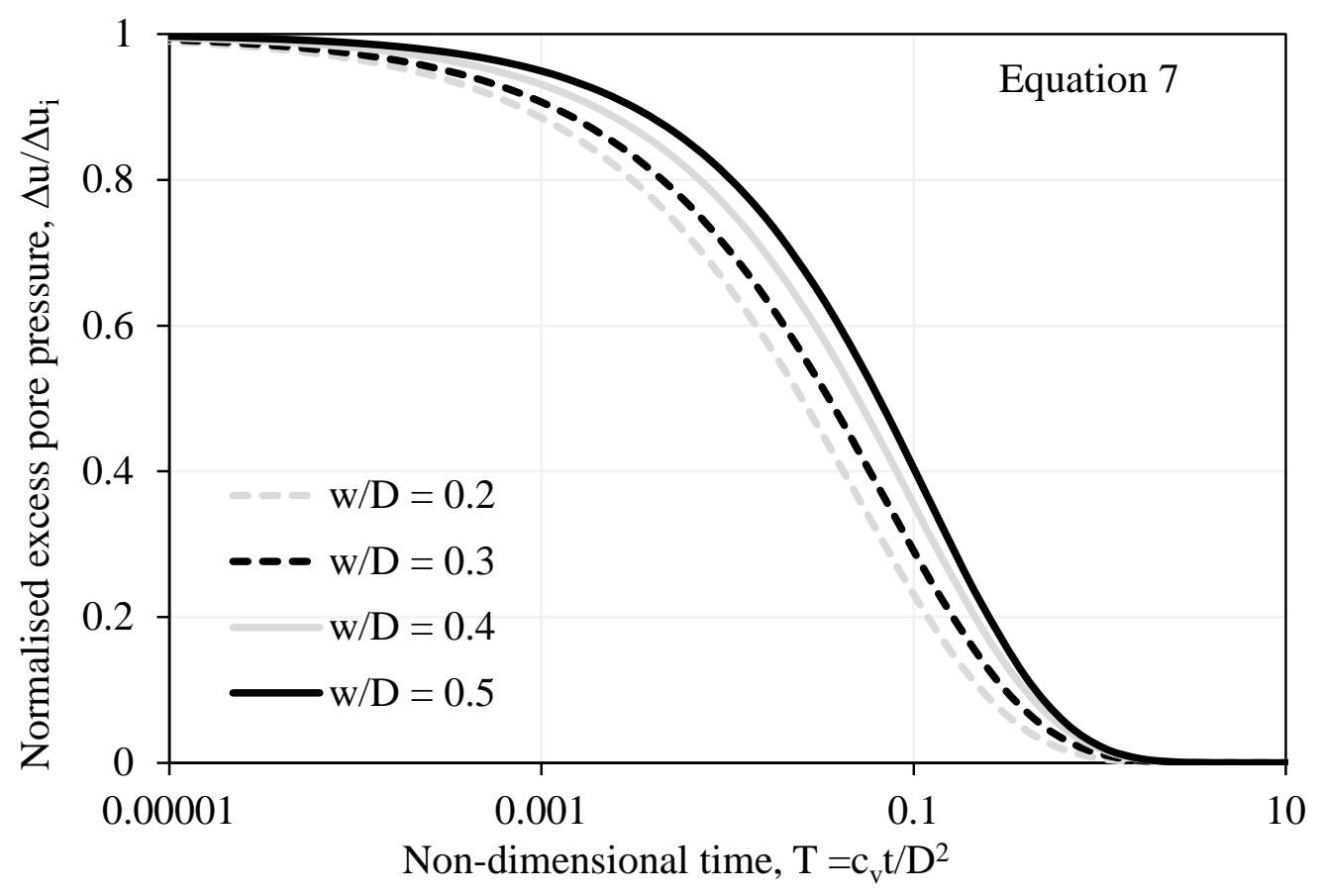

Figure 6 Fitted invert pore pressure dissipation time histories for range of embedment 
Assessment of the consolidated breakout response of partially embedded subsea pipelines.

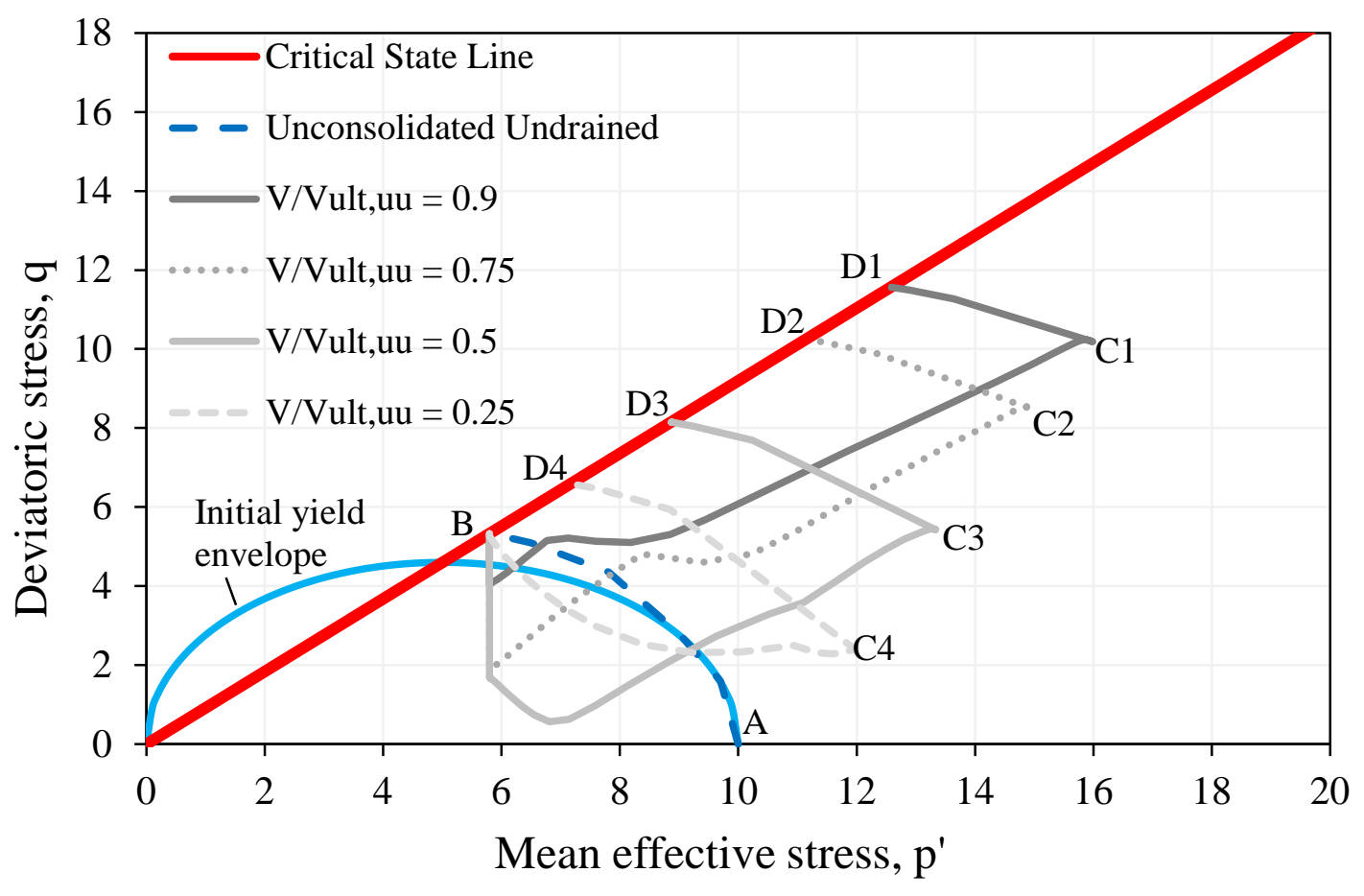

(a) $\mathrm{p}^{\prime}$-q space

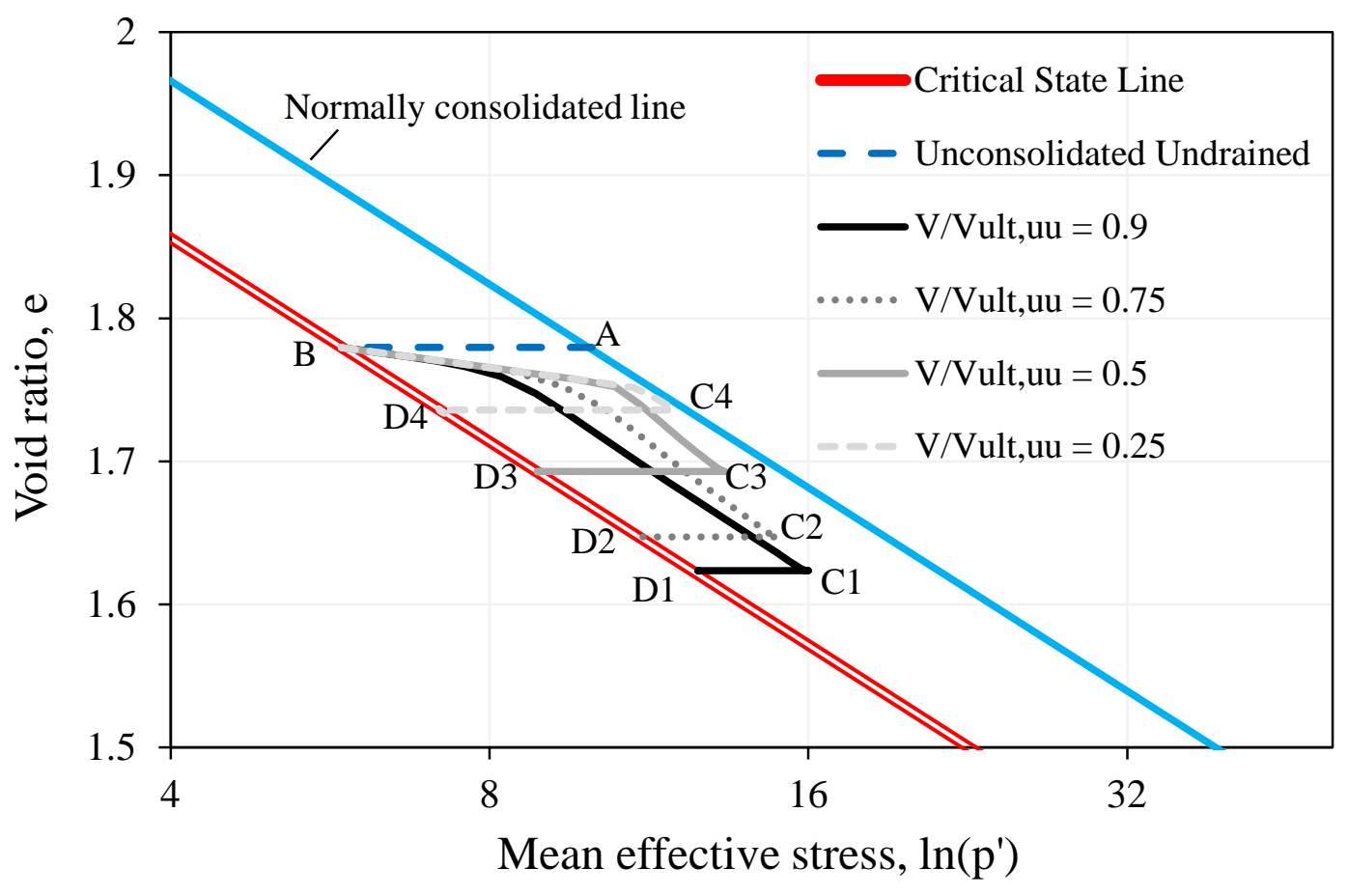

(b) e-ln(p') space

Figure 7 Stress paths at pipe invert during loading and consolidation $(w / D=0.5)$ 


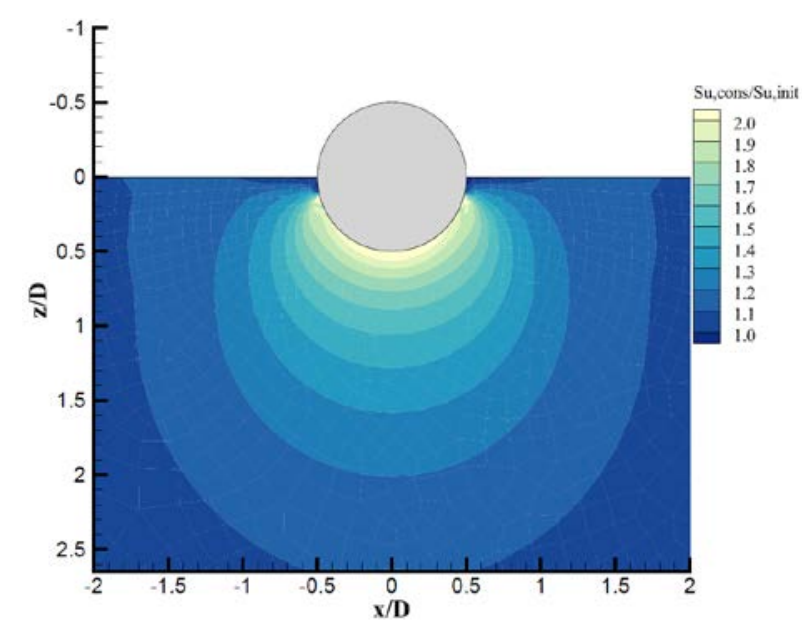

(a) $\mathrm{V} / \mathrm{V}_{\text {ult,Uu }}=0.9$

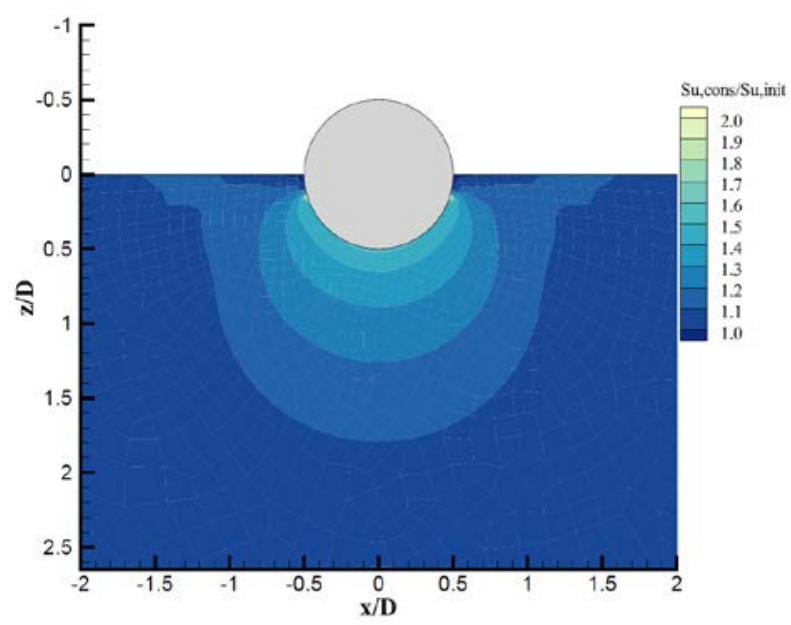

(c) $\mathrm{V} / \mathrm{V}_{\text {ult,Uu }}=0.5$

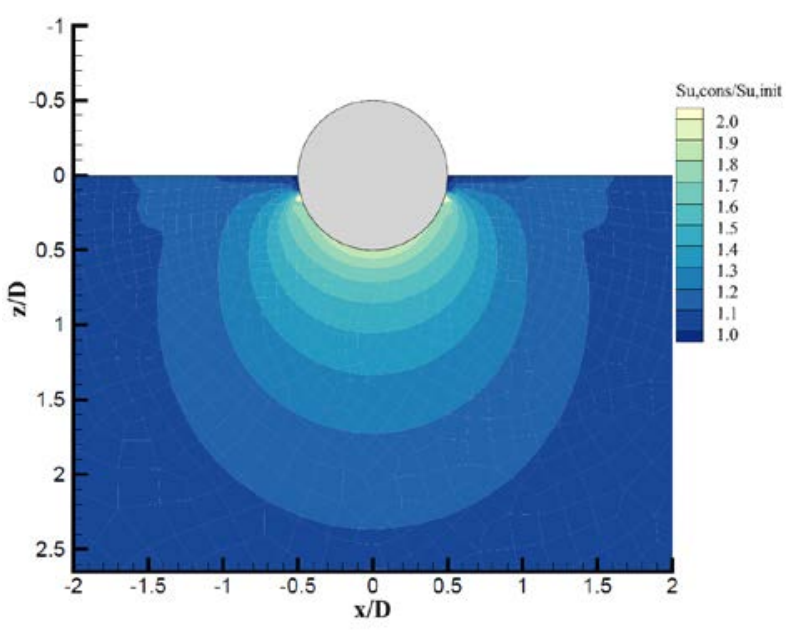

(b) $\mathrm{V} / \mathrm{V}_{\mathrm{ult}, \mathrm{UU}}=0.75$

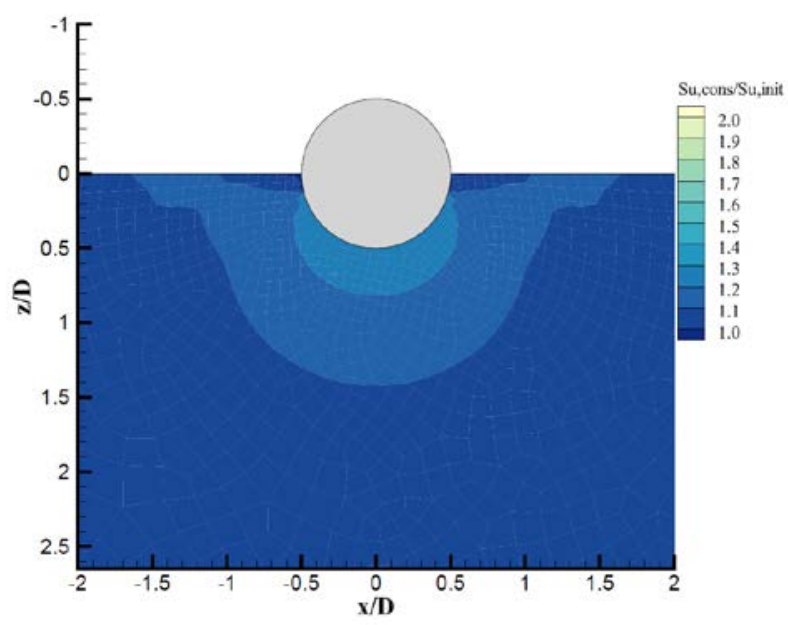

(d) $\mathrm{V} / \mathrm{V}_{\text {ult,UU }}=0.25$

Figure 8 Distribution of shear strength enhancement due to consolidation 


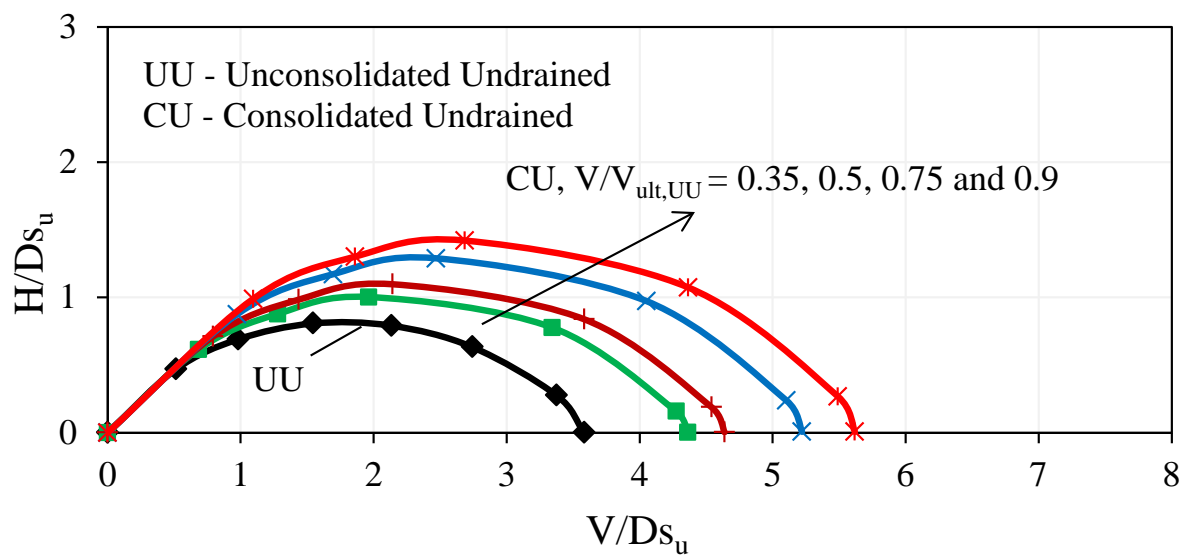

(a) $\mathrm{w} / \mathrm{D}=0.2$

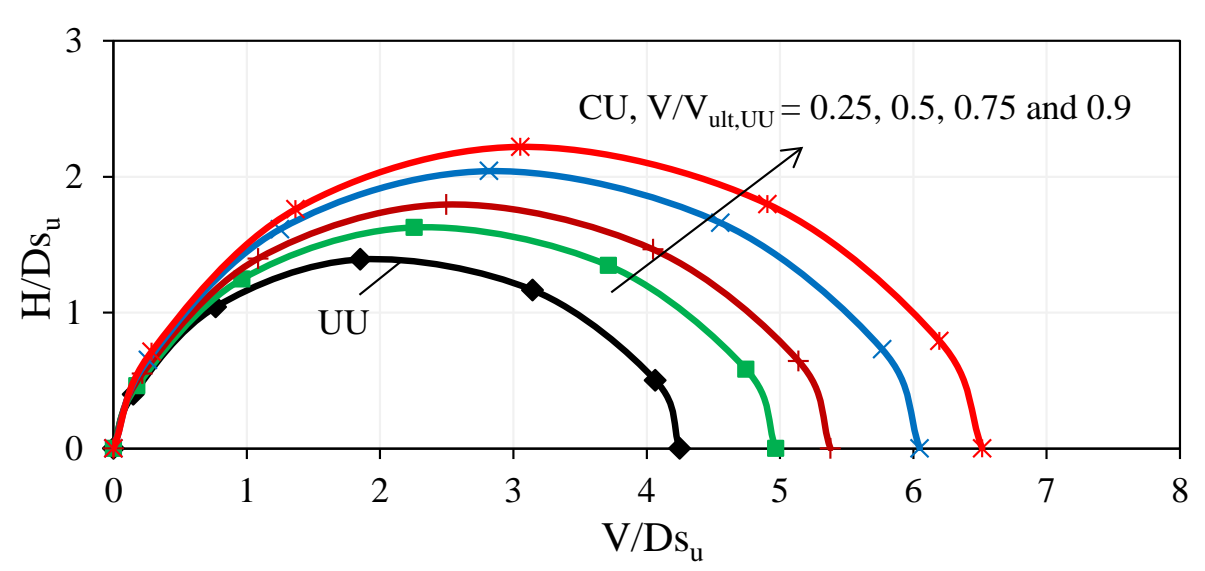

(c) $\mathrm{w} / \mathrm{D}=0.4$

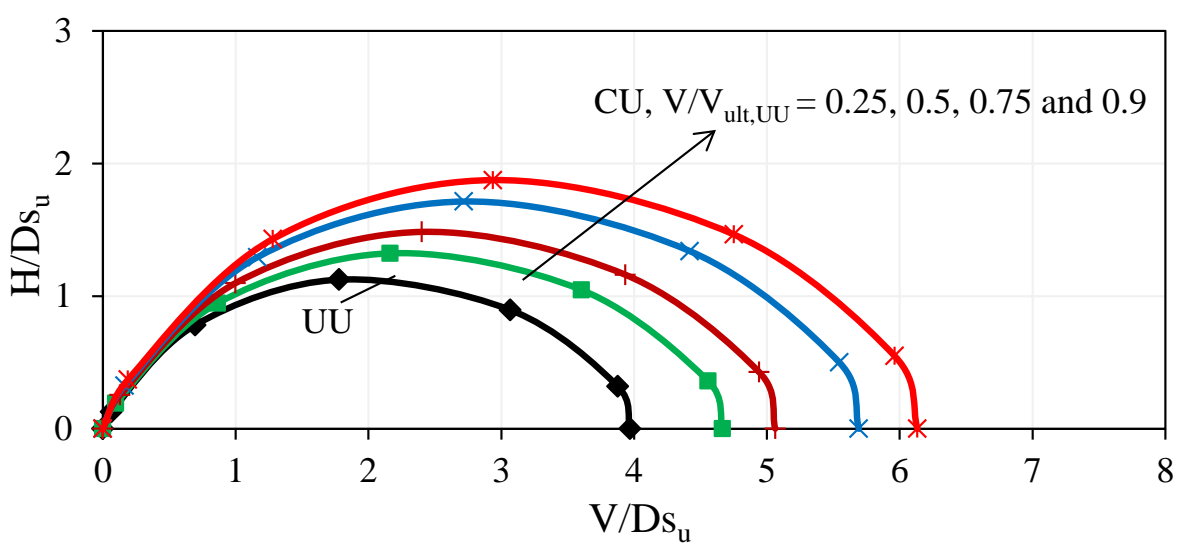

(b) $\mathrm{w} / \mathrm{D}=0.3$

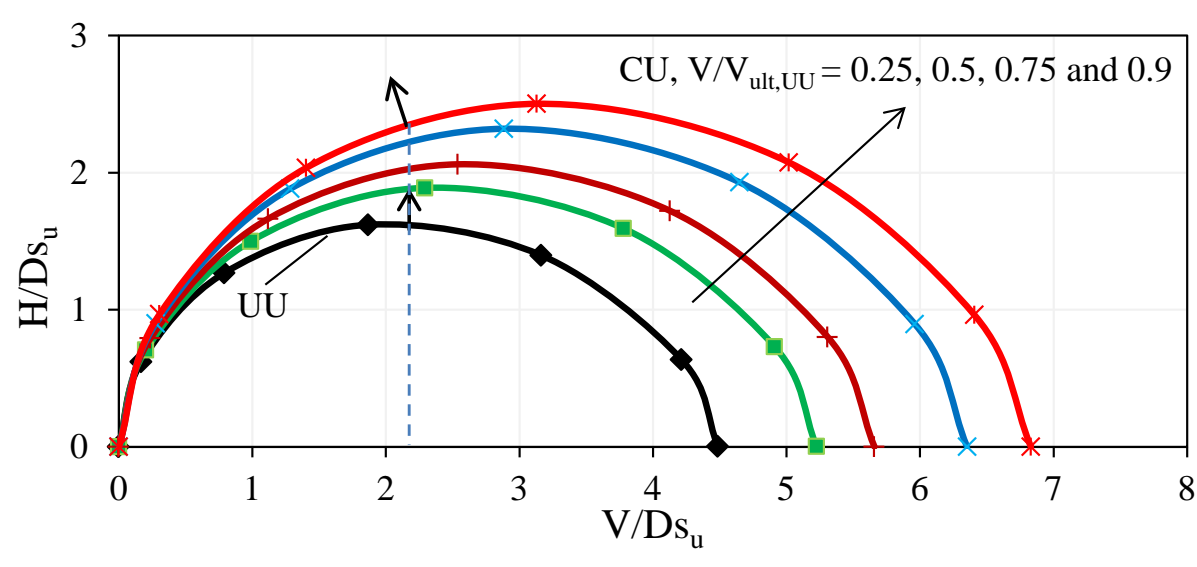

(d) $\mathrm{w} / \mathrm{D}=0.5$

Figure 9 Failure envelopes for unconsolidated and consolidated breakout 


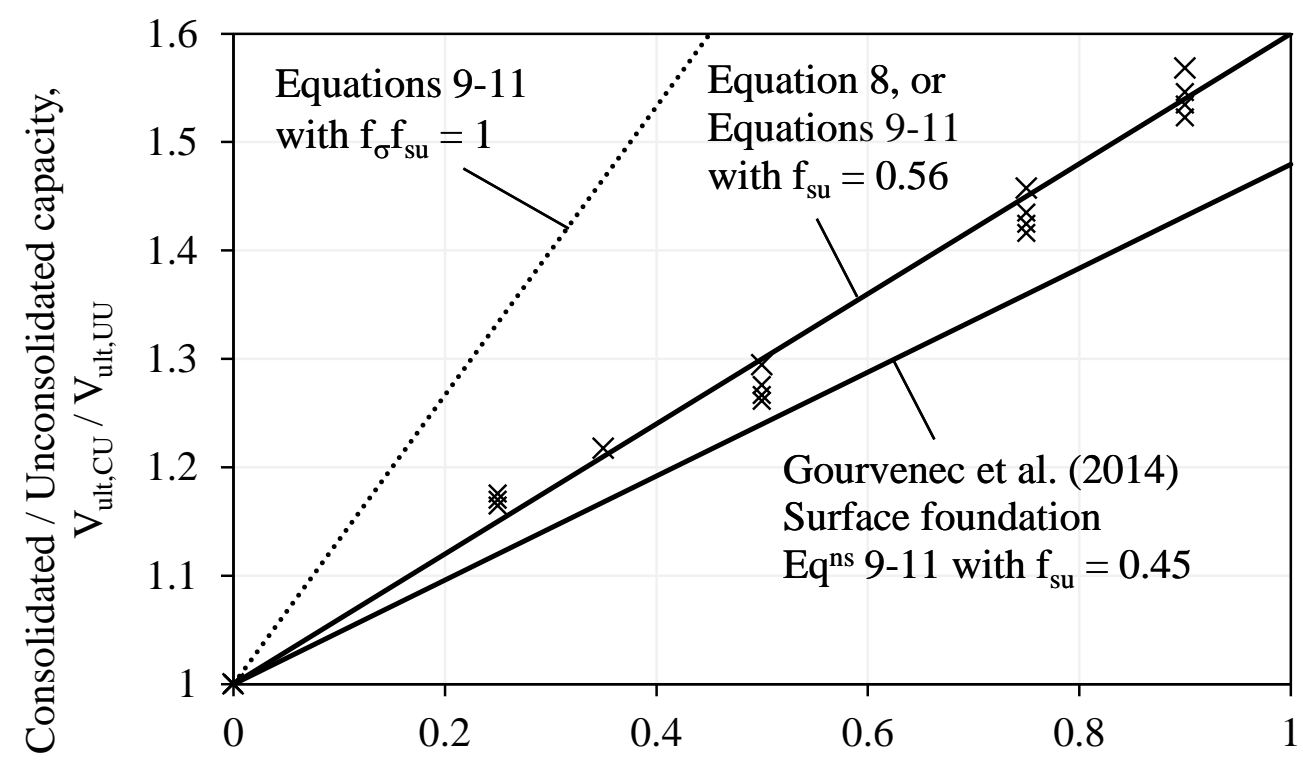

Consolidation load / Unconsolidated undrained capacity, $\mathrm{V} / \mathrm{V}_{\mathrm{ult}, \mathrm{UU}}$

Figure 10 Gain in undrained vertical capacity due to consolidation

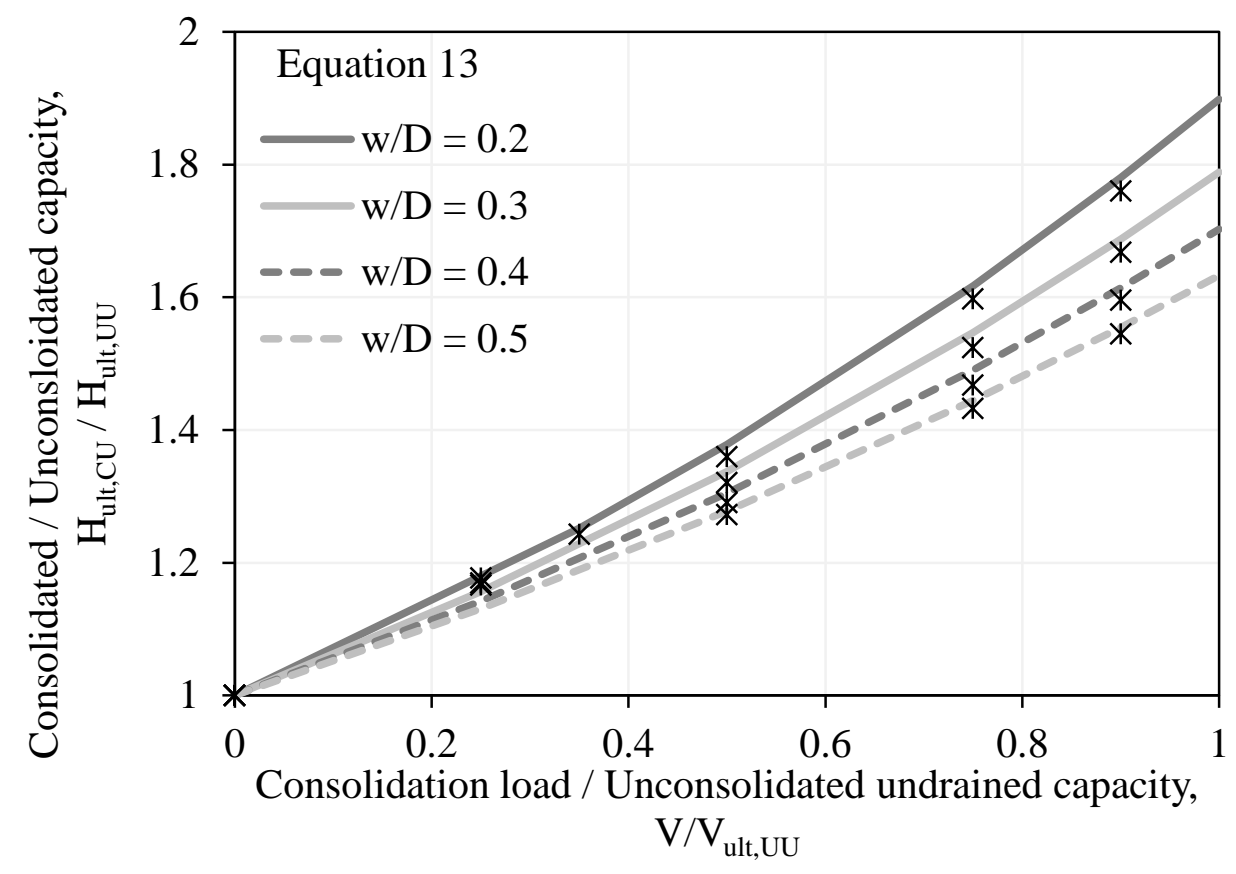

Figure 11 Gain in undrained horizontal capacity due to consolidation 
Assessment of the consolidated breakout response of partially embedded subsea pipelines.

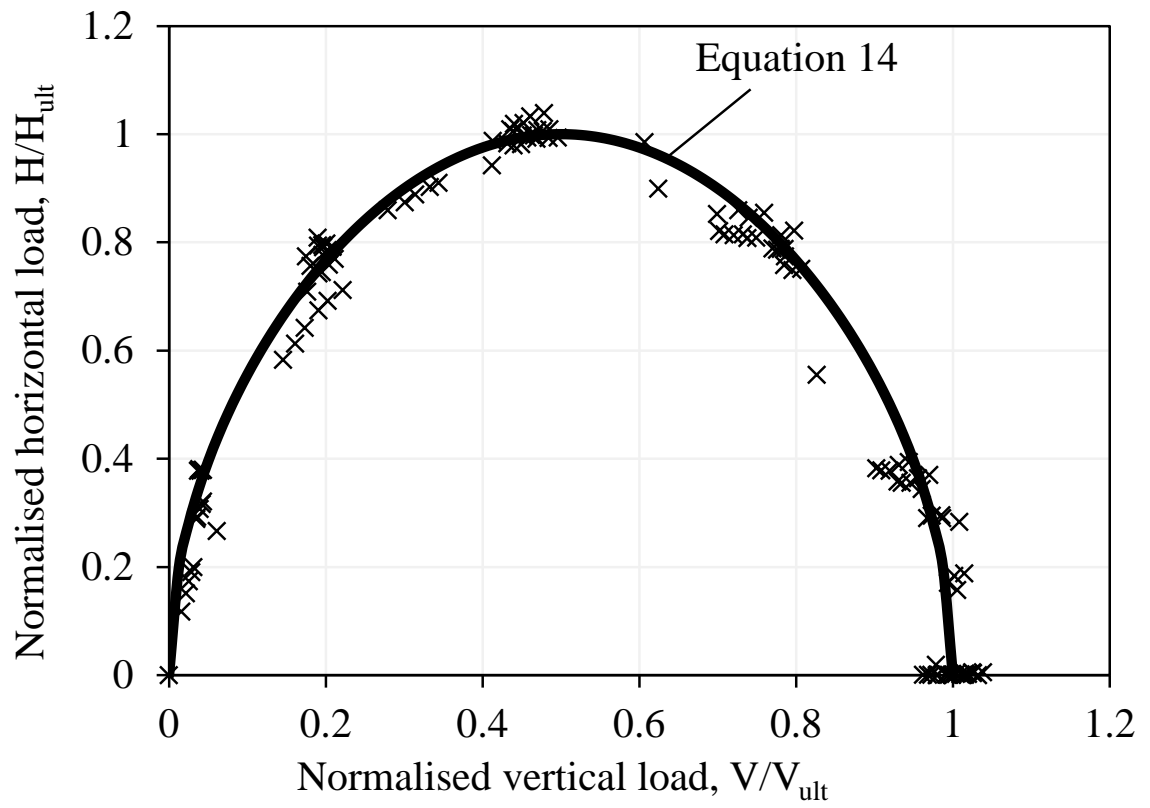

Figure 12 Normalised failure envelopes for consolidated undrained breakout 


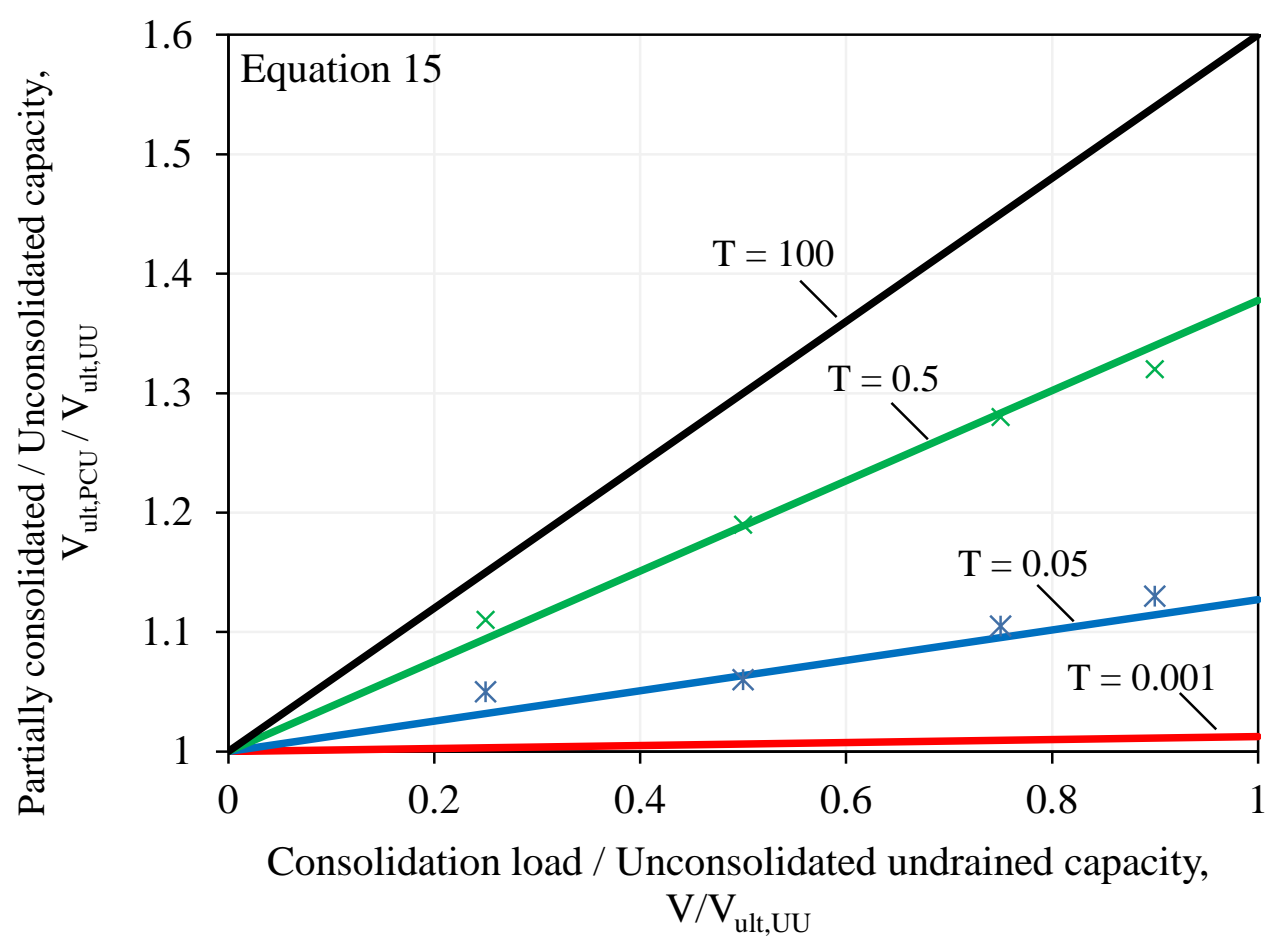

Figure 13 Effect of partial consolidation on undrained vertical capacity

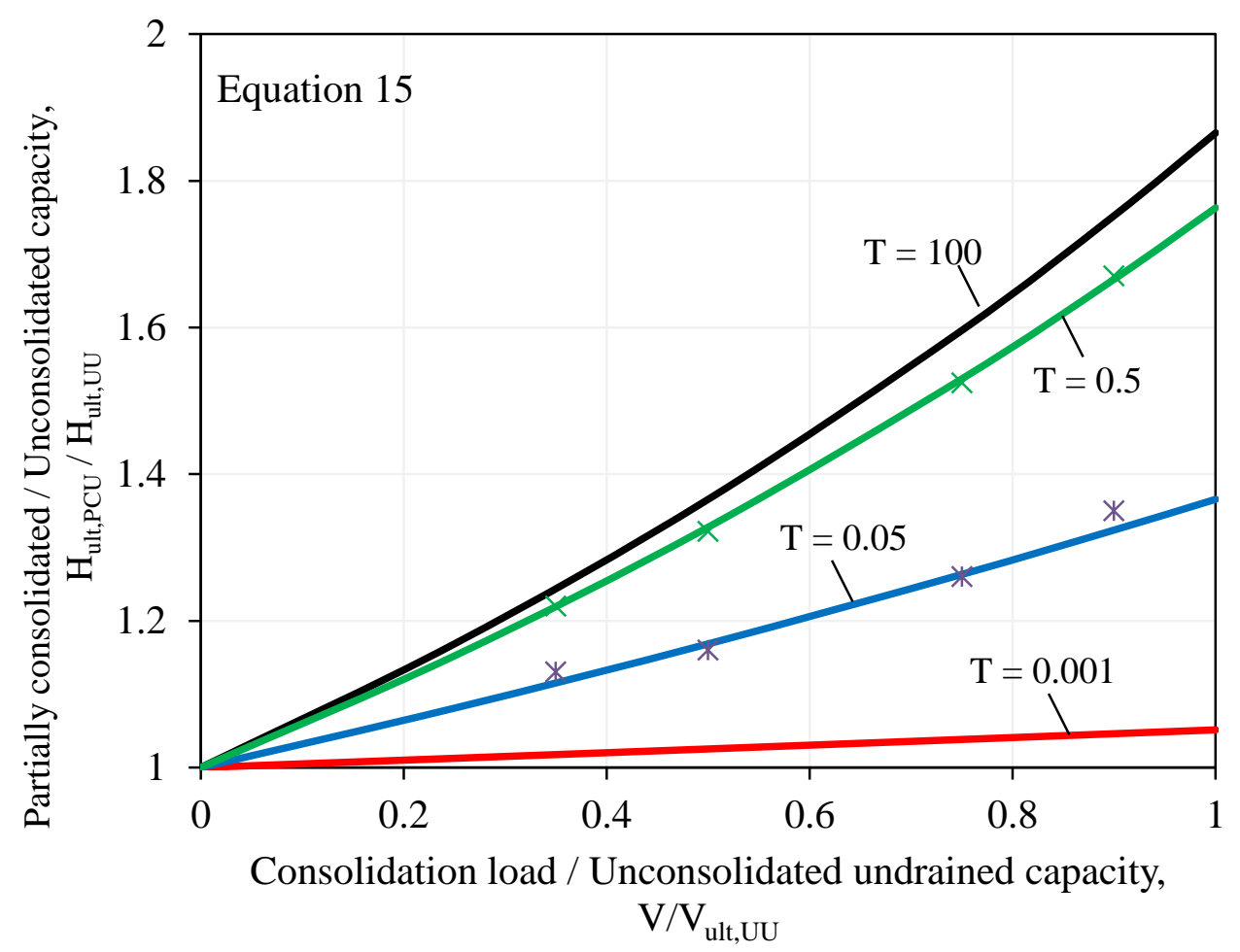

Figure 14 Effect of partial consolidation on undrained horizontal capacity (w/D = 0.2) 